\title{
Overview of nickel-based filler metals for brazing of austenitic stainless steels
}

\author{
M. A. Penyaz, Post-Graduate Student, Department No. 9 "Physical problems of materials science", \\ e-mail: mapenyaz@mephi.ru \\ A. A. Ivannikov, Senior Lecturer, Department No. 9 "Physical problems of materials science" , e-mail: ivannikov7@rambler.ru \\ O. N. Sevryukov, Associate Professor, Department No. 9 "Physical problems of materials science", e-mail: sevr54@mail.ru \\ B. A. Kalin, Professor, Department No. 9 "Physical problems of materials science"”, e-mail: bakalin@mephi.ru
}

${ }^{1}$ National Research Nuclear University "MEPHI", Moscow, Russia.

\begin{abstract}
For the manufacture of thin-walled precision structures with complex geometry, the method of brazing is used. It allows to obtain joints with a given structural-phase state, high mechanical characteristics and resistance to corrosion.

This overview examines alloys based on copper, precious metals, nickel and iron, which are actively used for joining steels. The data on the operational characteristics of the joints obtained by brazing using nickel-based filler metals are presented and structured.

Special attention is paid to nickel braze alloys based on $\mathrm{Ni}-\mathrm{B}, \mathrm{Ni}-\mathrm{Si}-\mathrm{B}, \mathrm{Ni}-\mathrm{Cr}-\mathrm{B}, \mathrm{Ni}-\mathrm{Cr}-\mathrm{Si}, \mathrm{Ni}-\mathrm{Cr}-\mathrm{Si}-\mathrm{B}$, $\mathrm{Ni}-\mathrm{Mn}, \mathrm{Ni}-\mathrm{Cr}-\mathrm{P}, \mathrm{Ni}-\mathrm{Si}-\mathrm{Be}$ systems. Such alloys are the most widespread and applicable throughout the world. The overview describes the main phases that are formed in the seams and the heat-affected zones of joints. The dependences of the technological parameters of the process, such as the temperature-time mode of brazing and the size of the gap on the microstructure of the joints and their mechanical characteristics, are shown. The corrosion resistance of steel joints brazed by various nickel-based filler metals is considered.

The overview is based on the extensive experience of MEPhl in the production and development of rapidly solidified amorphous-crystalline foils based on nickel. In addition to the world experience, the overview considers works of the research team of the MEPhl laboratory, which has been working on this topic since 1995. This overview will help technologists and designers of energy-intensive equipment to determine the trajectory for the selection of the filler metal composition to obtain the optimal technological parameters, mechanical characteristics and corrosion resistance of the joints applicable to a specific design problem.

Key words: austenitic steel, filler metal, brazing, structural phase state, energy-intensive technology, nickel, TLPbonding.

DOI: $10.17580 / \mathrm{nfm} .2021 .01 .06$
\end{abstract}

\section{Introduction. The brazing}

$\mathrm{T}$ he austenitic stainless steels, which are given the most attention in this overview, are widely used in many industries. The exceptional complex of properties of these steels allows them to be used as structural materials for components of nuclear reactors, diesel, aircraft and rocket engines, stationary gas turbines. The most complicated technological operations in the manufacture of structural elements are intermediate and final assemblies. In most cases, these operations are performed using various types of cutting and welding. Brazing is used for the manufacture of thin-walled precision structures with complex geometries, requiring a low quality of accuracy [1-2]. Brazed joints are able to withstand high temperatures, static and dynamic mechanical loads, and the influence of aggressive media for a long time without noticeable deterioration of their properties.

Depending on the tasks and the shape of the finished product, capillary brazing or "sandwich" brazing is used. In the case of capillary brazing, the filler metal is placed on the surface of the product outside the gap so that the molten braze alloy flows into the gap. This method can be used for products with complex geometries, but it requires good wettability and high fluidity of the filler metal. An example is the brazing of stepped outer air seal segment [3] made of stainless steel. This segment is a plate with honeycombs brazed by $\mathrm{Ni}-7 \mathrm{Cr}-4.5 \mathrm{Si}-3 \mathrm{Fe}-3 \mathrm{~B}$, wt.\% filler metal. In the work [4], this technology successfully solves the problem of brazing honeycombs from a thin nickel superalloy foil using a nickel-based filler metal $\mathrm{Ni}-18 \mathrm{Cr}-10 \mathrm{Si}$, wt. $\%$.

Thus, the processes of wetting and flowing of braze alloy into the gap are important parameters that must be taken into account in order to obtain a high-quality connection [5]. The ability of the brazed alloy to flow into the gap determines the height of its rise in the capillary, which is critical when joining parts of honeycomb structures, such as heat exchangers. For example, in the work [6], vacuum brazing of a steel intermediate heat exchanger (IHX) using a nickel-based filler metal $\mathrm{Ni}-$ $7 \mathrm{Cr}-4.5 \mathrm{Si}-3 \mathrm{Fe}-3 \mathrm{~B}$, wt.\% is considered. IHX is an important component of a high-temperature gas-cooled reactor (HTGR) [7], designed for a power and hydrogen production system. In addition to the growing reactor 
industry, there is a growing demand for environmentally friendly aircraft gas turbine engines with lower emissions and improved specific fuel consumption by incorporating heat exchangers in gas turbines. In the work [8], the design of steel and nickel heat exchangers, a gas turbine recuperator, an intercooler and a heat-removing air cooler, as well as their production technologies, including brazing, are considered.

In the general case of "sandwich" or "repair" brazing, the filler metal is placed directly between the two parts to be brazed. In the particular case for dissimilar materials, in addition to the filler metal, a spacer made of another material is placed, which serves as a transition layer to minimize thermal stresses during brazing. Repair brazing is widely used in the servicing of aircraft engines and stationary gas turbine components such as turbine and compressor blades which are exposed to extreme conditions. Cracks, hot gas wear, corrosion and shock damage can occur due to high temperatures and pressures, as well as exposure to foreign objects. To increase the service life of such details, maintenance and repair brazing process is carried out. For example, in the works [9-10] a modern development of a two-stage hybrid technology is presented, including the process of repair brazing of turbine blades using a nickel-based filler metal $\mathrm{Ni}-18.5 \mathrm{Cr}-10 \mathrm{Si}$ wt.\%. Such brazing can be used to repair both narrow gaps and wide gaps of surface defects in a turbine blade.

To obtain steel joints with high resistance to mechanical stress and fatigue, plastic braze alloys based on solid solutions or eutectics without intermetallics are usually used. Recently, however, the precision technology Transient Liquid Phase bonding (TLP bonding) has become widespread, in which brittle solder alloys can be used. TLP bonding has been around for a long time and is well described in the works [11-12]. This makes it possible to obtain joints from various materials with a given structural-phase state and a thickness of several tens of micrometers. Since the process is based on the diffusional redistribution of elements, alloys containing so-called Melting Point Depressant elements (MPD elements) are used for joining, as a rule, having high diffusion activity and lowering the melting point of the alloys (for example, $\mathrm{B}, \mathrm{Si}$, and to a lesser degree $\mathrm{P}$ ). The joining process is carried out with isothermal exposure at a temperature between the liquidus of the filler alloy and the solidus of the base material [13], during which thermally activated diffusion occurs between the base material and the braze alloy melt [14]. During diffusion processes, the liquidus temperature of the liquid interlayer increases due to the mutual diffusion of the braze alloy elements and the base material, which leads to isothermal solidification [15]. The isothermal holding time depends on the size of the gap or the thickness / amount of the filler metal, its melting range, the presence of refractory elements and the relative content of the depressant [16-17].

It is known that the size of the brazed gap has a great influence on the properties of the joints obtained using brazing. Plastic filler metals, for example, based on $\mathrm{Ni}-$ $\mathrm{Au}, \mathrm{Ni}-\mathrm{Pd}$, are applicable for obtaining joints with both small $(<100 \mu \mathrm{m})$ and large $(>100 \mu \mathrm{m})$ gaps. When brazing with small gaps, due to the diffusion redistribution in the seam, a structure is formed that is very different from the structure of the original filler metal. When brazing with large gaps or during "repair" brazing, the structural-phase state of the used filler metal is formed in the seam, and the strength properties of such a joint are determined by the strength properties of the braze alloy. However, using brittle eutectic alloys containing MPD elements, it is possible to obtain highly plastic joints in case of large gaps. For this purpose, the technology "wide gap brazing" is used [18]. The method consists in mixing a powder of a brittle eutectic braze alloy and a powder (filler) of based material or pure metal. The filler is a drain for the diffusion of MPD elements from the eutectic braze alloy. In this case, the same calculations are used as in TLP bonding [19-20], which make it possible to determine the required brazing temperature and isothermal holding time to obtain a plastic solid solution structure in the seam without brittle phases [21].

Since the process of brazing of austenitic steels is associated with a large number of technological requirements, a limited number of filler metals are used. The overview considers the main braze alloys that are used to create products of energy-intensive equipment, that is operated at high temperatures in the loaded state.

\section{Filler metals for brazing austenitic stainless steels}

Filler metals can be obtained in various forms: strip, wire, powders, paste [22], flexible brazing foil with an organic binder [23], amorphous foils, etc. [24]. The type of braze alloy, depending on the specific engineering task, influences the choice of the elemental composition of the alloy. Some alloy systems can only be obtained in certain forms, while others are available in all forms. In addition, the type of filler metal can provide both precision and automated assembly for brazing. For example, a wire or strip of braze alloy can be fed automatically during the assembly of parts, which is well suited for brazing individual assemblies or small batch production. In the case of amorphous foils obtained by rapid solidification of a plane melt jet [24-25], it is possible to implement a precision assembly for brazing a detail of a complex configuration using blanks of special geometry. The advantages of using such filler metal blanks are as follows: ease of use; a constant amount of braze alloy. The disadvantages include: high cost, inaccuracy in the location of the filler metal blank due to manufacturing tolerances. The most popular are filler metals in the form of powders and pastes. Powders are produced by a variety of methods, including spraying and crushing [26]. The powder is applied by suspension (powder plus a suitable binder), by dusting (spraying the powder onto the surface), or by spraying with a binder through an applicator similar to a paint sprayer. 
The basic systems of filler metals are alloys based on copper, precious metals, nickel and iron, which, with a certain choice of composition, can be obtained in all the forms listed above. When brazing stainless steels, filler metals based on elements such as copper, silver, nickel and gold are mainly used, depending on the required mechanical characteristics, the corrosive environment and the operating temperature of the product. The most promising for brazing of complexly stressed products are braze alloys in the form of microcrystalline powders or amorphous foils, which will be given the most attention in this overview.

According to the classification of the American Welding Society (AWS), industrial brazing alloys of the $\mathrm{BAg}, \mathrm{BAu}, \mathrm{BCu}$, BNi series are applicable for brazing stainless steels [27]. Analogues of these solders exist in many standards, for example, alloys according to standard of DIN EN ISO 17672:2016 "Brazing - Filler metals" or specification of Aerospace Material Specification (AMS).

Among the copper filler metals, the most suitable for brazing of steels are: AWS $\mathrm{BCu}-1, \mathrm{BCu}-1 \mathrm{a}, \mathrm{BCu}-1 \mathrm{~b}$, $\mathrm{BCu}-2$ и $\mathrm{BCu}-3$ (Fig. 1). These alloys are commonly used for brazing carbon steels, high-alloy and stainless steels, nickel and copper-nickel-based alloys. Since copper is a "soft" metal, brazed joints obtained with it can withstand heavy loads and have good ductility, which provides high resistance to fatigue. However, studies of corrosion resistance of the brazed joint obtained at $T_{\text {braze }}=1130^{\circ} \mathrm{C}$ using $\mathrm{BCu}-1$ brazing alloy demonstrate in water the presence of selective corrosion along the grain boundaries of copper crystals. Filler metals based on the $\mathrm{Cu}-\mathrm{P}$ system are undesirable for brazing steels and nickel alloys, since brittle phosphides are formed.

There are a number of Russian brazing alloys based on $\mathrm{Cu}-\mathrm{Zn}-\mathrm{Mn}, \mathrm{Cu}-\mathrm{Mn}-\mathrm{Ni}$ systems (32-39 wt.\% Mn, $<5$ wt. $\% \mathrm{Ni}$ ), where $\mathrm{Mn}$ as well as Ni increases the strength of the joints and lowers the melting point of the filler metal. However, alloys with $\mathrm{Mn}$ are prone to liquation. The filler metals VPr2 $(\mathrm{Cu}-24 \mathrm{Mn}-5.5 \mathrm{Ni}-1.0 \mathrm{Fe}-0.2 \mathrm{Li}$ wt.\%, $\left.T_{\text {melting }}=980-1000{ }^{\circ} \mathrm{C}\right)$ and $\operatorname{VPr} 4(\mathrm{Cu}-29 \mathrm{Mn}-29 \mathrm{Ni}-$ $1.0 \mathrm{Si}-1.0 \mathrm{Fe}-0.2 \mathrm{Li}, T_{\text {melting }}=1000-1050^{\circ} \mathrm{C}$ ) provide a higher heat resistance of brazed joints made of stainless steels (up to $\sim 600^{\circ} \mathrm{C}$ ) than silver-based filler metals (up to $\left.370-500^{\circ} \mathrm{C}\right)$.

Among the existing 39 silver-based braze alloys of AWS classification, there are not many suitable for joining steels, since silver does not wet iron-based alloys well. Silver-based filler metals have valuable properties: they are plastic and heat-resistant. Silver-based filler metals containing zinc, tin, manganese and nickel are recommended for joining stainless steels (Figure 1). In work [28] the use of AMS 4772 silver-based braze alloy $(54 \mathrm{Ag}-40 \mathrm{Cu}-$ $5 \mathrm{Zn}-1 \mathrm{Ni}$, wt.\%) for brazing stainless steel AISI 321 with a nickel superalloy is considered. For brazing stainless steels AISI 300 and 400, the BAg-21 and BAg-23 braze alloys are of the greatest interest. The first is suitable for brazing in a furnace in a protective atmosphere due to the absence of zinc and cadmium. The nickel in the compo-

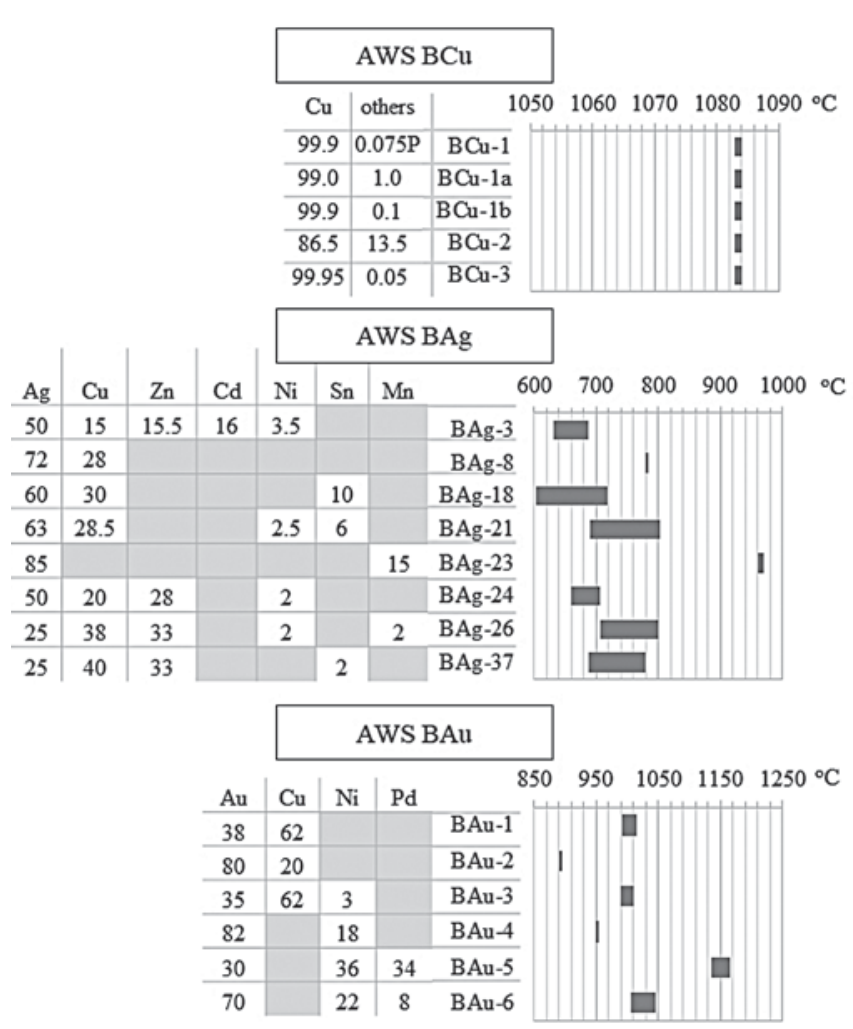

Fig. 1. Brazing alloys based on copper, silver and gold are most suitable for brazing stainless steels according to the AWS classification (the compositions are indicated in wt.\%)

sition makes the joint insensitivity to crevice corrosion by creating a nickel-rich layer along the edge of the fillet. BAg-23 is mainly used for brazing stainless steels, nickelor cobalt-based alloys when operating the product at high temperatures. However, due to the presence of manganese, it is not suitable for work in high vacuum conditions.

Among the gold filler metals of the AWS BAu series, several alloys are applicable for brazing iron-, nickel- and cobalt-based alloys (Fig. 1). These alloys provide great resistance to oxidation, corrosion and, at the same time, they are extremely ductile. They are often used for thinwalled structures due to their low speed of interaction with the base material. In work [29] an investigation of brazing process of stainless steel AMS 5510 using braze alloy AMS 4787 (BAu-4) was conducted. One application of this is the creation of components for the fuel systems of aircraft engines. In work [30] the connection of a shape memory alloy $\mathrm{Ti}_{50} \mathrm{Ni}_{50}$ with stainless steel AISI 316L using filler metal BAu- 6 is considered. The application of this method is promising for some engineering tasks.

Gold-based filler metals are of great practical interest. Due to this, studies of their properties are being carried out, such as, for example, the fatigue behavior of AISI 304L / BAu-4 brazed joints [31].

In addition to widely known industrial braze alloys, a series of iron-based filler metals has been developed. Their use is limited due to their fragility, difficulty in obtaining and a high melting point of about $1200{ }^{\circ} \mathrm{C}$. To reduce the 
melting temperature, silicon, boron and phosphorus are doped into them, and tungsten and chromium are doped to increase the heat resistance. Since these alloys have a low plasticity, they are used in the form of powder or pastes. However, in recent years, the demand for iron-based filler metals has been growing due to the high cost of nickelbased alloys and stricter environmental requirements for the industry [32]. With regard to the brazing of stainless steels, iron-based filler metals can be divided into two types: with a phosphorus content and with a boron content. In works [16, 33-34] alloys based on the $\mathrm{Fe}-$ $\mathrm{Si}-\mathrm{B}$ system $(\mathrm{Fe}-5.3 \mathrm{Si}-3 \mathrm{~B}$ and $\mathrm{Fe}-12 \mathrm{Cr}-7.5 \mathrm{Si}-$ $2 \mathrm{~B}$ wt.\%) with a brazing temperature in the range of $1200-1220{ }^{\circ} \mathrm{C}$ and brazing alloys grade $\mathrm{F} 302(\mathrm{Fe}-$ $15 \mathrm{Cr}-10 \mathrm{Ni}-9 \mathrm{P}-5 \mathrm{Si}-5 \mathrm{Cu}$, wt.\%) and $\mathrm{F} 300(\mathrm{Fe}-$ $24 \mathrm{Cr}-20 \mathrm{Ni}-7 \mathrm{P}-5 \mathrm{Si}-10 \mathrm{Cu}-5 \mathrm{Mn})$ with a lower brazing temperature of $1100{ }^{\circ} \mathrm{C}$, due to the presence of phosphorus, are considered. The addition of this element provides improved wettability and flow properties of the steel. The corrosion resistance in an acidic environment of joints obtained with Fe-based brazing alloys containing $\mathrm{P}$ is significantly higher than that of joints obtained with $\mathrm{Fe}$ - and Ni-based brazing alloys containing B [35]. However, the main disadvantage of filler metals with $\mathrm{P}$ in comparison with filler metals with $\mathrm{B}$ is their low strength properties.

The series of nickel-based braze alloys is the most extensive and universal, while these alloys meet the highest requirements for corrosion resistance, strength and, most importantly, stable operation at elevated temperatures $\left(600 \ldots 800^{\circ} \mathrm{C}\right)$, since they have a de-brazing temperature comparable to the melting point of steel. Whereas the most common filler metals based on silver, copper and other elements are widely used for brazing structures, which are heat-resistant only up to $400 \ldots 500{ }^{\circ} \mathrm{C}$ and do not meet a number of other requirements [36].

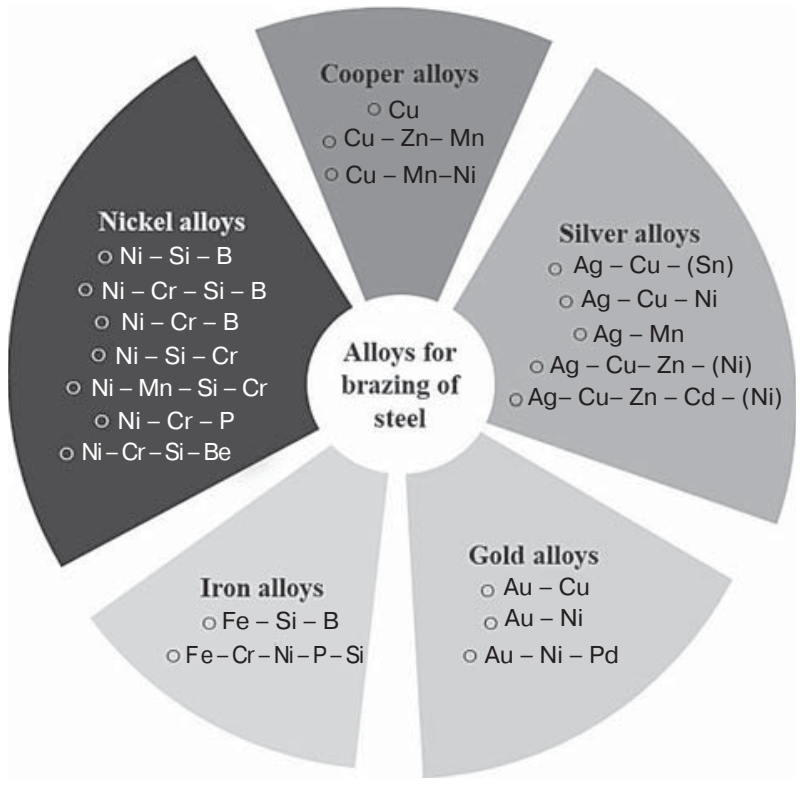

Fig. 2. Brazing systems based on copper, silver, gold, iron and nickel, most suitable for brazing stainless steels
Therefore, the next chapter of the overview is devoted to these alloys. The systems of elements, on the basis of which industrial alloys exist and experimental alloys are being developed, as well as research directions for finding new systems, will be considered in detail.

A general diagram of the filler metal systems for brazing steels is shown in Fig. 2.

\section{Nickel-based filler metals}

In recent years the development and application of nickel-based filler metals has been determined by increased requirements for brazed joints made of stainless steels or nickel superalloys. Complex alloyed nickel-based alloys are widely used in practice, as opposed to simple systems.

The melting point of pure nickel is $1453{ }^{\circ} \mathrm{C}$. It should be noted that the brazing temperature for most steels should not exceed $1140-1170{ }^{\circ} \mathrm{C}$, since the recrystallization process actively proceeds above these temperatures [37-38]. The required low-melting point of nickel-based filler metals is achieved by alloying with elements that form eutectics or more low-melting solid solutions with nickel. This is $\mathrm{S}, \mathrm{Sb}, \mathrm{Sn}, \mathrm{P}, \mathrm{Si}, \mathrm{B}, \mathrm{Be}, \mathrm{Cr}, \mathrm{Mn}, \mathrm{Au}$. The first three elements cause strong embrittlement of nickel alloys and steels, so their introduction into braze alloy is impractical. Further in Table 1, the main binaries systems are considered, which are the basis for the development of nickel-based braze alloys.

As noted earlier, elements that lower the melting point and participate in diffusion redistribution due to diffusion activity are called MPD elements. These elements include $\mathrm{Si}, \mathrm{B}, \mathrm{P}$. Although $\mathrm{Cr}$ also lowers the melting point of the nickel alloy, its main function is to increase the strength and heat resistance of the nickel alloy. Therefore, it is usually combined with $\mathrm{B}, \mathrm{P}$ and $\mathrm{Mn}$ to lower the melting point.

Phosphorus-containing brazing alloys are widely used for brazing steels. Most brazing alloys with phosphorus are eutectic based, and their feature is an exceptional surface spreading and a low melting point. When developing filler metals based on $\mathrm{Ni}-\mathrm{P}$ system, $\mathrm{Si}, \mathrm{Fe}, \mathrm{Co}, \mathrm{Mn}$ and $\mathrm{Cu}$ are added to the alloys. Filler metals based on the $\mathrm{Ni}-\mathrm{P}$ system do not require the use of fluxes, they have high ductility at elevated temperatures and corrosion resistance (the latter are subject to chromium alloying). However, they also have disadvantages: due to the high content of $\mathrm{P}$, brittle phosphides appear at the interface of the joint with steel, which causes embrittlement of the brazed joints [36].

However, the most commonly used brazing alloys for brazing of stainless steels are nickel-based alloys containing B. Alloys based on the $\mathrm{Ni}-\mathrm{B}$ system are effectively used in the case when it is required to sharply increase the de-brazing temperature of the joint, provided that there are no restrictions on erosion, that is, for products of large cross-sections. Alloying with boron in small amounts $(0.05-0.30 \mathrm{wt} . \% \mathrm{~B})$ is carried 
Table 1

Binaries systems promising for nickel-based braze alloy development [39]

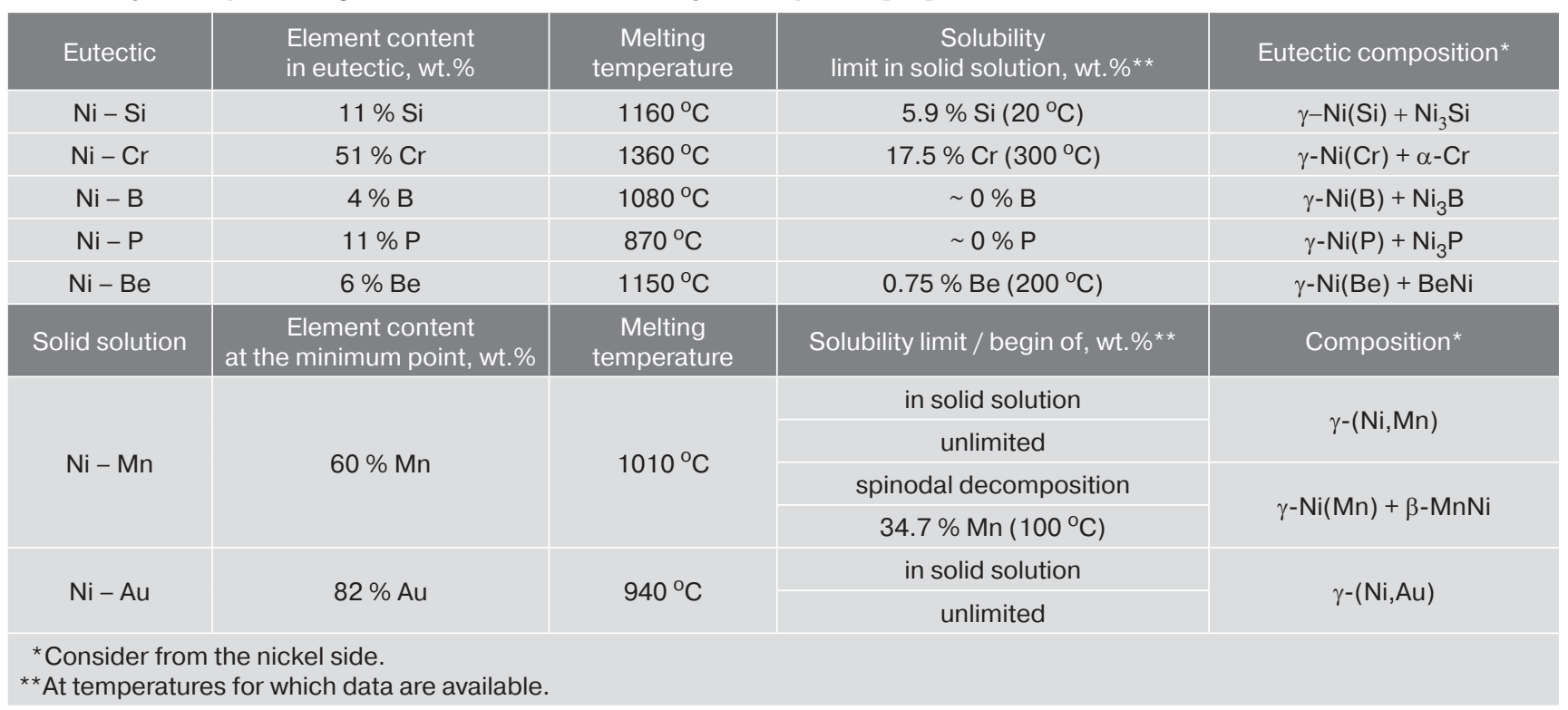

out to improve the technological properties: wettability, self-fluxing property and spreading over the base material. If the goal is to lower the melting point of the alloy, more than 2 wt.\% B is added to it. However, Ni - B binary alloys have not gained widespread acceptance as braze alloys. They are low-plastic due to the presence of brittle borides, and they are used in the form of powders. Due to the absence of such alloying elements as $\mathrm{Cr}$ and $\mathrm{Si}$, these filler metals provide low corrosion resistance of a joint. Therefore, brazing alloys based on $\mathrm{Ni}-\mathrm{Cr}-$ $\mathrm{Si}-\mathrm{B}$ system are much more applicable. They have a melting point lower than the melting point of the $\mathrm{Ni}-\mathrm{B}$ eutectic alloys, and they provide improved properties of a joint. However, the problem of boride formation along the grain boundaries of the brazed material remains for complex systems, which is well considered in [40-42].

Recently, the development of a braze alloy, which provides an increase of heat resistance, plasticity and debrazing temperature, occurs in two directions. The first is to reduce the content of boron and phosphorus to such amounts that do not cause their intergranular penetration into base material during brazing process. The second is to reduce in the silicon content in order to increase the strength and ductility of the brazed joints by introducing additional alloying elements with more suitable properties. For example, in works [43-46] the compositions of nickel-based brazing alloys that do not contain metalloids are considered. However, it is not possible to obtain liquidus temperature acceptable for brazing steels on these alloys, therefore they are suitable only for brazing nickel superalloys.

Further, the features and the possibility of using several groups of nickel-based filler metals will be considered in more detail.

\section{Filler metals based on $\mathrm{Ni}-\mathrm{Si}-\mathrm{B}$ and $\mathrm{Ni}-\mathrm{Cr}-\mathrm{Si}-\mathrm{B}$ systems}

Taking into account the development of nickel-based braze alloys, many thermodynamic studies of the threecomponent $\mathrm{Ni}-\mathrm{Si}-\mathrm{B}$ system have been carried out. A number of successful braze alloys have been created on the basis of the ternary eutectic in this system. The most common alloys of BNi series of AWS standard, as well as some Russian alloys VPr [47] and STEMET [48] (amorphous nickel-based foils), are shown in Fig. 3.

These alloys are used not only for brazing stainless steels with each other [49-50], but also for creating dissimilar joints of steel with various materials. Thus, for example, they are shown to be promising for brazing AISI 316 steel with a high-entropy alloy $\mathrm{CoCrFe}(\mathrm{Mn}) \mathrm{Ni}$ [5152]; nickel superalloy IN718 with AISI 304 steel in normal and ultrafine states [53-54], as well as with AISI 316L steel [55]; nickel superalloy Inconel X-750 with duplex steel SAF 2205 [56-57]; nitrogen-containing duplex steel SAF 2507 with steel AISI 304 [15]; martensitic steel AISI 420 with steel SAF 2507 [58] and many other applications.

Alloys $\mathrm{BNi}-3$ and $\mathrm{BNi}-4$ based on the $\mathrm{Ni}-\mathrm{Si}-\mathrm{B}$ system (Fig. 3) have received great development, since they have low solidus and liquidus temperatures and are still of interest from the point of view of studying this elemental system. In works [59-62] phase equilibria, the liquidus surface, and isothermal sections in this system were investigated. Most interesting is the nickel angle at which there are different eutectic reactions. On its basis, numerous braze alloys of the $\mathrm{Ni}-\mathrm{Si}-\mathrm{B}$ system were created.

The existing phase transformations are given below [63]: Nonvariant transformations:

$$
\begin{aligned}
L \leftrightarrow \mathrm{Ni}_{2} \mathrm{~B}+\mathrm{Ni}_{3} \mathrm{~B}+\mathrm{Ni}_{6} \mathrm{Si}_{2} \mathrm{~B}\left(990^{\circ} \mathrm{C}\right) \\
L \leftrightarrow \gamma-\mathrm{Ni}+\mathrm{Ni}_{3} \mathrm{~B}+\mathrm{Ni}_{6} \mathrm{Si}_{2} \mathrm{~B}\left(985^{\circ} \mathrm{C}\right)
\end{aligned}
$$


Fig. 3. Nickel-based brazing alloys, most suitable for brazing stainless steels according to AWS classification and Russian grades (compositions are indicated in wt.\%)

\begin{tabular}{|c|c|c|c|c|c|c|c|c|c|c|}
\hline \multirow[b]{2}{*}{$\mathrm{Ni}$} & \multirow[b]{2}{*}{$\mathrm{Cr}$} & \multirow[b]{2}{*}{$\mathrm{Fe}$} & \multirow[b]{2}{*}{$\mathrm{Si}$} & \multirow[b]{2}{*}{ B } & \multicolumn{3}{|c|}{ AWS BNi } & \multirow[b]{2}{*}{900} & & \multirow[b]{2}{*}{$1200^{\circ} \mathrm{C}$} \\
\hline & & & & & $\mathrm{P}$ & others & 800 & & 10001100 & \\
\hline bal & 14.0 & 4.5 & 4.5 & 3.0 & & $0.8 \mathrm{C}$ & $\mathrm{BN}_{\mathrm{i}-1}$ & & $\square$ & \\
\hline bal & 7.0 & 3.0 & 4.5 & 3.2 & & & $\mathrm{BN}_{\mathrm{i}-2}$ & & $\square$ & \\
\hline bal & & & 4.5 & 3.2 & & & $\mathrm{BNi}_{\mathrm{i}-3}$ & & & \\
\hline bal & & & 3.5 & 2.2 & & & $\mathrm{BNi}_{-4}$ & & & \\
\hline bal & 18.5 & & 10.0 & - & & & $\mathrm{BNi}^{-5}$ & & & \\
\hline bal & 19.0 & & 7.3 & 1.5 & & & $B N-5 a$ & & & \\
\hline bal & & & & & 11.0 & & $\mathrm{BNi}-6$ & $\square$ & & \\
\hline bal & 14.0 & & & & 10.0 & & $\mathrm{BNi}-7$ & I & & \\
\hline bal & & & 7.0 & & & $22 \mathrm{Mn}, 4 \mathrm{Cu}$ & $\mathrm{BNi}-8$ & & $\square$ & \\
\hline bal & 15.0 & & & 4.0 & & & BNi-9 & & $\square$ & \\
\hline bal & 12.0 & 3.0 & 3.5 & 2.5 & & $16 \mathrm{~W}, 0.5 \mathrm{C}$ & $\mathrm{BN}_{\mathrm{i}}-10$ & & & \\
\hline bal & 10.0 & 3.0 & 4.0 & 2.5 & & $11.5 \mathrm{~W}$ & BNi-11 & & & \\
\hline bal & 25.0 & 0.2 & 0.1 & & 10.0 & & BNi-12 & L & & \\
\hline
\end{tabular}

\begin{tabular}{|c|c|c|c|c|c|c|c|c|c|c|c|}
\hline \multirow[b]{2}{*}{$\mathrm{Ni}$} & \multirow[b]{2}{*}{$\mathrm{Cr}$} & \multirow[b]{2}{*}{$\mathrm{Fe}$} & \multirow[b]{2}{*}{$\mathrm{Si}$} & \multirow[b]{2}{*}{ B } & \multirow[b]{2}{*}{$\mathrm{Mn}$} & \multirow[b]{2}{*}{ Mo } & \multirow[b]{2}{*}{ others } & Russian braze alloys & \multirow[b]{2}{*}{900} & & \multirow[b]{2}{*}{$1200^{\circ} \mathrm{C}$} \\
\hline & & & & & & & & 800 & & 10001100 & \\
\hline bal & 7.0 & 4.0 & 4.0 & 3.0 & & & & STEMET 1301 & & $\square$ & \\
\hline bal & 15.0 & 4.0 & 7.5 & 1.5 & & 4.0 & & STEMET 1309 & & & \\
\hline bal & 0.3 & 5.0 & 4.0 & 3.5 & & & $16 \mathrm{Co}$ & STEMET 1311 & & $\square$ & \\
\hline bal & & & 1.0 & 0.1 & 34 & & $10 \mathrm{Co}, 2 \mathrm{Nb}$ & $\operatorname{VPr} 7$ & & 口 & \\
\hline bal & & & 0.5 & & 33.5 & & $4.0-9.5 \mathrm{Nb}, 4.0-9.5 \mathrm{~W}, 10.0-11.5 \mathrm{Co}$ & VPr8 & & I & \\
\hline bal & 15.0 & 4.0 & 4.5 & 2.5 & & & $0.6 \mathrm{C}, 0.1-1.0 \mathrm{Al}$ & VPr11 & & $\square$ & \\
\hline bal & 9.0 & 0.4 & & 2.5 & & 2.0 & $9 \mathrm{~W}, 1.5 \mathrm{Nb}, 9 \mathrm{Co}, 1.5 \mathrm{Al}$ & VPr 27 & & $\square$ & \\
\hline bal & 9.0 & & 6.0 & 1.2 & & 1.2 & $6 \mathrm{~W}, 14 \mathrm{Co}$ & VPr42 & & & \\
\hline bal & 19.0 & & 6.0 & 1.3 & & 5.0 & $1 \mathrm{Nb}, 9 \mathrm{Co}$ & VPr 50 & & & \\
\hline bal & 9.0 & & & & 40.5 & & $6.0-8.0 \mathrm{Fe} ; 0.10-0.25 \mathrm{~B}$ & $\mathrm{Mn} 40 \mathrm{NiCr}$ & & & \\
\hline bal & 5.0 & & 4.7 & & 70.0 & & & $\mathrm{Mn} 70 \mathrm{NiCr}$ & & $\square$ & \\
\hline
\end{tabular}

\section{Monovariant transformations:}

$l \leftrightarrow \mathrm{Ni}_{3} \mathrm{~B}+\mathrm{Ni}_{6} \mathrm{Si}_{2} \mathrm{~B}\left(1000^{\circ} \mathrm{C}\right)$

$l \leftrightarrow \mathrm{Ni}_{2} \mathrm{~B}+\mathrm{Ni}_{6} \mathrm{Si}_{2} \mathrm{~B}\left(1000^{\circ} \mathrm{C}\right)$

The location of the transformation curves in the ternary diagram explains the wider melting range of $\mathrm{BNi}-4$ alloy compared to BNi-3 alloy (Fig. 3), despite their similar compositions. Shifting the composition to the region of lower silicon and boron contents increases the melting range and thereby provides the filler metal with the ability to fill wider gaps. Due to the reduced amount of metalloids in the BNi-4 alloy and the absence of other alloying elements, it is suitable for brazing of stainless steel assemblies where ductile joints are required. At the same time, the BNi-3 alloy, due to its higher content of metalloids, has better flow characteristics, therefore it is an excellent choice for capillary brazing of components with large overlaps.

When alloying BNi-3 and BNi-4 alloys with chromium in an amount of no more than $10 \mathrm{wt} . \%$, the liquidus and solidus temperatures become even lower, for example, as in the alloys BNi-2 $\left(T_{1}=1024^{\circ} \mathrm{C}\right)$ and STEMET $1301\left(T_{1}=1010^{\circ} \mathrm{C}\right)$ (Fig. 3). An increase in chromium above $10 \%$ leads to an increase in the liquidus temperature to $1100{ }^{\circ} \mathrm{C}$, as in the $\mathrm{BNi}-1$ alloy, which contains
15 wt.\% Cr. Additional alloying with carbon, as in the case of VPr11, neutralizes the effect of a high chromium content on melting temperature. The liquidus temperature for VPr 11 is $1020^{\circ} \mathrm{C}$. The $\mathrm{BNi}-2$ brazing alloy is the most widely used of nickel-based filler metals. Its properties are similar to the BNi-1 alloy, but it has a much lower liquidus temperature (Fig. 3).

Described nickel-based alloys are typically used where operating conditions require resistance to corrosion and high operating temperatures. Applications - highly stressed parts, such as jet engine components and assemblies, used in corrosive high temperature environments, such as nuclear reactor products, jet engine diffusers and honeycomb assemblies. These filler metals can also be used at temperatures below zero, such as the temperature of liquid oxygen, helium, or nitrogen. The BNi series of alloys have a low vapor pressure, which makes the brazed designs suitable for high vacuum service.

Separately, it should be said about the alloys BNi-10, BNi-11 and VPr27 - these are the most heat-resistant of the nickel-based filler metals. Tungsten in their composition is used as a hardener of the nickel matrix, which makes these alloys applicable for brazing heat-resistant steels and alloys containing cobalt, molybdenum and tungsten. Their use for brazing stainless steels may not be 
economically feasible and requires consideration of a specific design problem. The wide melting range of these filler metals is also suitable for "repair" brazing.

Returning to the alloys based on the $\mathrm{Ni}-\mathrm{Cr}-\mathrm{Si}-\mathrm{B}$ system (Fig. 3), which have received a greater development in the industry (BNi-1, BNi-2, VPr11, STEMET 1301 etc.). For decades, interest in this system of alloys has not waned. There have been many studies of brazed joints [64-71].

In these studies, it was found that the structure of a seam and the heat-affected zone depends on many parameters, such as the temperature-time mode of brazing, the gap between the parts, the type of filler metal used (foil, powder, paste, etc.) [72]. Also, the seam is often the seam itself and the fillet area. Metallographic and micro$X$-ray spectral studies of joints show that the microstructure of a seam and the fillet area differ significantly in their structural-phase state. In the fillet area, due to the large volume of the braze alloy melt, the diffusion of MDP elements into the base material does not have time to pass. Therefore, chromium borides and nickel silicides crystallize, which make up an eutectic in the initial filler metal, which can be clearly observed using the example of the AISI 321/STEMET 1301 (analogue of BNi-2) joint in Fig. 4. The presence of such brittle phases in large quantities adversely affects the fatigue strength and corrosion resistance of brazed joints [73]. The microstructure of the central part of a seam, where a gap is $30-50 \mu \mathrm{m}$ (Fig. 4), is represented by a nickel-based solid solution, containing iron, chromium, silicon. There are no borides in this section of the seam. During brazing, the liquid braze alloy actively interacts with the solid base material. Boron and silicon actively diffuse from the melt of braze alloy into the brazed material adjacent to the seam. A significant concentration gradient at the interface between the liquid filler metal and the base material promotes diffusion processes, and the liquid filler metal crystallizes as a solid solution under isothermal conditions with a long holding time [74].

In the direction from the interface to the depth of the base metal, the amount of dispersed precipitates decreases, but a boride network is formed along the grain boundaries of the base material [76]. It should be noted that a similar picture is observed when brazing nickel-based superalloys [77-78]. As a result, when the joint is cooled in wider gaps, about $150 \mu \mathrm{m}$ in size (including in the fillet area), rather large needle-shaped chromium borides crystallize (dark phases in Fig. 4). This structure is characterized by low mechanical characteristics under thermal cyclic loads due to different properties of brittle borides and a base material [42] and low corrosion resistance due to chromium depletion of the region near the seam [35, 79].

It should be noted that the role of boron as the main element considered in TLP bonding, is somewhat overestimated. It has been shown in a number of works that the duration of the TLP bonding depends to a greater extent on the diffusion of silicon. Silicon has a low diffusion coefficient in steel and nickel alloys, in contrast

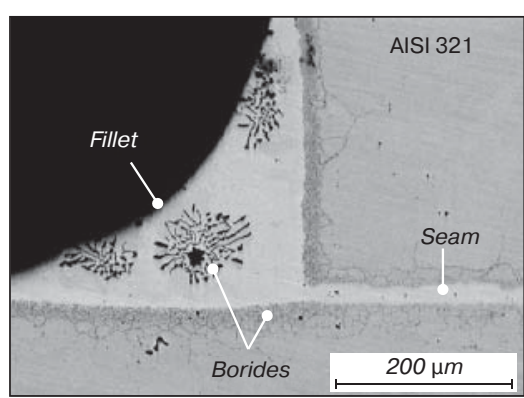

Fig. 4. Microstructure of AISI 321/STEMET 1301 brazed joint; mode $1100{ }^{\circ} \mathrm{C} 15 \min [75]$

to boron, and its outflow slows down the isothermal solidification [80-81].

Brazed alloys based on the $\mathrm{Ni}-\mathrm{Cr}-\mathrm{B}$ system are also known. With a content of $13-20 \mathrm{wt} . \% \mathrm{Cr}$ and 3-5 wt.\% $\mathrm{B}$, the melting range is $1010-1090{ }^{\circ} \mathrm{C}$. A ternary eutectic $(\mathrm{Ni}-15 \mathrm{Cr}-3.5 \mathrm{~B}$ wt.\%) exists in this system with a melting point of $1055^{\circ} \mathrm{C}$. The BNi-9 alloy (Fig. 3) is developed based on this eutectic. It is particularly well suited for TLP bonding. Depending on the diffusion time and the brazing temperature, the de-brazing temperature of the joint can be higher than $1370{ }^{\circ} \mathrm{C}$. With a longer holding time, the seam grains increase in size in a brazed joint due to the absorption of adjacent grains of the base material. Since the filler metal is a eutectic alloy, the liquation problem is eliminated. However, the use of such alloys does not solve the problem of the formation of brittle boron phases in the diffusion zone.

Many years of experience in the operation of brazed products from stainless steels and numerous laboratory experiments show that the BNi-2 alloy is still a universal brazing alloy for joining steels for most applications. Therefore, it is considered in most works as the basis for research, optimization and development of new braze alloys. The direction of a corrosion damage mechanisms investigation for a brazed joint and improvement of its corrosion resistance are of great interest.

The corrosion effect in a joint area in the case of a $\mathrm{BNi}-2$ alloy begins mainly in the diffusion zone on the side of the base material due to the formation of chromium borides and a low nickel content [82]. Also, this zone is the region of crack initiation under superimposed corrosion-fatigue loading [83]. The corrosive environment significantly reduces a tensile strength and a fatigue strength of a brazed joint, while practically does not effect the characteristics of the base material AISI 304L [84]. An increase in a chromium content in a filler metal to concentrations of $13-18 \mathrm{wt} . \%$ has a positive effect on the microstructure formation and helps to prevent chromium depletion of steel grains, which in turn also has a positive effect on the resistance to intergranular corrosion [75] and minimizes the contribution of the environment during corrosion fatigue. An increase in the chromium content, as well as the addition of molybdenum, as in the STEMET 1309 braze alloy (Fig. 3), significantly reduces the amount 
of brittle borides in the diffusion zone. It is known that the boron content in the filler metal cannot be reduced to less than $1.5 \mathrm{wt} . \%$, since it provides a low brazing temperature [89-90].

There is also a direction of research dedicated to the possibility of partial replacement of expensive nickel with iron. The influence of the iron concentration in the $\mathrm{BNi}-2$ alloy on its temperature range of melting and properties is investigated. The addition of an alloying element such as iron reduces the erosion activity of a filler metal and lowers the liquidus temperature, with the addition of no more than $25 \mathrm{wt} . \%$. A decrease in the liquidus temperature from $1035{ }^{\circ} \mathrm{C}$ to $980{ }^{\circ} \mathrm{C}$ was also noted. It was shown that the addition of iron instead of nickel does not lead to a decrease in mechanical characteristics and deterioration of corrosion properties [87].

In some works, it is noted that the introduction of cobalt improves the ductility and heat resistance of nickel alloys, while its significant amount does not noticeably change the liquidus temperature, since it has similar thermophysical properties with nickel [36].

\section{Filler metals based on the $\mathrm{Ni}-\mathrm{Si}-\mathrm{Cr}$ system}

For brazing of various steels, heat-resistant brazing alloys based on the $\mathrm{Ni}-\mathrm{Si}-\mathrm{Cr}$ system are widely used. Chromium, which is present in nickel, provides resistance to oxidation and gas corrosion due to the formation of a protective film. In addition to increasing the corrosion resistance, the advantage of chromium is that it significantly increases the strength properties of nickel at operating elevated temperatures. For example, the short-term strength of nickel at $400{ }^{\circ} \mathrm{C}$ is $220 \mathrm{MPa}$, and the shortterm strength of nickel alloyed with $20 \%$ chromium at the same temperature is $760 \mathrm{MPa}$ [38].

However, it should be borne in mind that, despite the fact that chromium increases the strength and heat resistance of the alloy, brazing alloys based on the $\mathrm{Ni}-\mathrm{Cr}$ system have a high melting point, unsuitable for brazing steels. A decrease in the melting temperature is achieved by introducing $\mathrm{Si}$ into their composition. Alloys based on the $\mathrm{Ni}-\mathrm{Si}-\mathrm{Cr}$ system are widely used as filler metals [36]. According to the $\mathrm{Ni}-\mathrm{Cr}-\mathrm{Si}$ ternary diagram [42] the lowest melting point of $1077^{\circ} \mathrm{C}$ corresponds to the ternary eutectic of $20.5 \mathrm{wt} . \% \mathrm{Cr}$ and $11.8 \mathrm{wt} . \% \mathrm{Si}$. The silicon content should be minimized when creating braze alloys, since brittle silicides are formed with iron and nickel.

The most famous and widely used filler metal of this system is the $\mathrm{BNi}-5$ alloy $\left(\mathrm{Ni}-18 \mathrm{Cr}-10 \mathrm{Si}, T_{\text {braze }}=\right.$ $=1150-1200{ }^{\circ} \mathrm{C}$ ), the composition of which is near the point of the ternary eutectic. When brazing with alloys of the $\mathrm{Ni}-\mathrm{Cr}-\mathrm{Si}$ system, the gap width must be taken into account. If it is higher than $25-30 \mu \mathrm{m}$, then brittle silicide phases are formed due to the large volume of silicon in the melt. In this case, it is necessary to carry out heat treatment (additional holding time at high temperature) of the brazed joint for dissolution of the silicide phase. There are developments in which silicon in nickel-based braze alloys is partially or completely replaced by germanium. Unlike silicon, germanium has a lower tendency to form brittle phases [36].

The second most common alloy after $\mathrm{BN}-2, \mathrm{BNi}-5$ alloy is boron-free, and it suitable for certain nuclear applications. Due to its high silicon content, BNi-5 filler metal is a good choice for capillary brazing or for brazing parts with large overlaps. The high chromium content is an advantage for components operating under severe corrosive or oxidizing conditions.

The $\mathrm{BNi}-5 \mathrm{a}$ alloy is a modified $\mathrm{BNi}-5$ alloy composition with a reduced $\mathrm{Si}$ content and a small $\mathrm{B}$ addition. The BNi-5a filler metal can be used instead of the BNi-1 alloy when lower boron levels are required. Typical applications for it are to braze thin honeycomb elements to basic sheet metal parts.

Here it is worth mentioning separately the Russian alloys of VPr42 and VPr50 (Fig. 3), which can also be used for brazing heat-resistant steels and nickel-based superalloys. In the case of brazing stainless steels, it is required, as mentioned earlier, to consider a specific design problem, since the brazing temperature with these alloys is about $1150{ }^{\circ} \mathrm{C}$ and the steel must have a high resistance to recrystallization. VPr42 and VPr50 contain 1.2-1.3 wt.\% B, and $6 \mathrm{wt} . \% \mathrm{Si}$ is added to reduce the liquidus temperature. These braze alloys can be considered intermediate in composition between the $\mathrm{BNi}-2$ and $\mathrm{BNi}-5$ alloys, that is, analogs of the BNi-5a alloy. However, unlike BNi-5a, these alloys contain $\mathrm{Co}, \mathrm{Nb}, \mathrm{W}$ and $\mathrm{Mo}$, so they are more suitable for brazing nickel-based superalloys.

\section{Filler metals based on the $\mathrm{Ni}-\mathrm{Mn}-\mathrm{Si}-\mathrm{Cr}$ system}

Filler metals of the $\mathrm{Ni}-\mathrm{Mn}$ system are used in the form of alloys with a solid solution structure ( $\mathrm{Mn} 40 \mathrm{NiCr}$, Mn70NiCr, VPr7, VPr8, Fig. 3) or alloys in which the eutectic prevails due to the addition of silicon (BNi-8). The advantage of these braze alloys is that the structural inhomogeneity of joints is minimized. Such filler metals provide high strength properties of joints. The disadvantages of Ni-Mn alloys are low corrosion resistance in aggressive environments and the limited ability to change the temperatures of the liquidus and solidus. Alloys $\mathrm{Mn} 40 \mathrm{NiCr}$ and $\mathrm{Mn} 70 \mathrm{NiCr}$ can be rolled into a foil with a thickness of at least $80-100 \mu \mathrm{m}$. Much more opportunities for creating braze alloys with desired properties are available when using eutectic alloys. Among the known alloys close to eutectic, there is an alloy $\mathrm{BNi}-8$.

Manganese alloying of alloys based on the $\mathrm{Ni}-\mathrm{Cr}-\mathrm{Si}$ system significantly improves the spreading of the braze alloy melt over steels. A noticeable decrease in the melting point is observed with the alloying of 6-8 wt.\% Mn. With the alloying of more than 15 wt.\% Mn, filler metals seriously dissolve a brazed material. This fact complicates their use for joining thin-walled products. The $\mathrm{BNi}-8$ alloy is near-eutectic, as mentioned above, and has a melting range of $982-1010{ }^{\circ} \mathrm{C}$. Brazing with this filler metal can be carried out at temperatures from $1050{ }^{\circ} \mathrm{C}$. 
The $\mathrm{BNi}-8$ alloy is used to create honeycomb structures from corrosion-resistant materials.

One of the disadvantages of manganese-containing braze alloys is the complexity of their application technology. Since manganese oxidizes faster than chromium, the gas (hydrogen, argon or helium) as the brazing medium must be clean and very dry, with a dew point of $-57^{\circ} \mathrm{C}$ or lower. The vacuum atmosphere must have a low oxygen partial pressure. Heating is usually done quickly enough to avoid evaporation of manganese from the filler metal. The use of nickel-based brazing alloys with manganese for high temperature applications is very limited, as alloying with manganese reduces the resistance to gas corrosion.

To summarize the overview of boron-containing nickelbased alloys, alloys based on the $\mathrm{Ni}-\mathrm{Cr}-\mathrm{Si}$ and $\mathrm{Ni}-\mathrm{Mn}$ systems. Due to the lack of solubility of boron in nickel and steel, brittle phases are formed in the brazed joints, which make the brazed joints brittle. This effect cannot be eliminated by heat treatment. Braze alloys containing boron are brittle by themselves and are not suitable for large gap brazing. At the same time, boron is the most effective additive for temperature reduction in nickel-based alloys. Alloys based on the $\mathrm{Ni}-\mathrm{Cr}-\mathrm{Si}$ system are not as brittle as alloys with boron, and with their help brazing over large gaps is possible. However, these alloys have a significantly higher melting point, which in some cases is not suitable for joining steels. Due to the high solubility of silicon in nickel and steel, for the $\mathrm{Ni}-\mathrm{Cr}-\mathrm{Si}$-based alloys a long isothermal process leads to the dissolution of silicides and the formation of a plastic joint.

Alloys based on the $\mathrm{Ni}-\mathrm{Mn}$ system can be obtained in the form of plastic foils with a thickness of at least 80$100 \mu \mathrm{m}$. However, brazed joints produced with this class of brazing alloys exhibit low corrosion resistance at elevated temperatures. The use of manganese-containing alloys is associated with a large number of technological difficulties, which was described above.

\section{Filler metals based on the $\mathrm{Ni}-\mathrm{Cr}-\mathrm{P}$ system}

Most $\mathrm{Ni}-\mathrm{P}$ alloys are eutectic based. A characteristic feature of phosphorous-containing filler metals is their exceptional spreadability over the surface of the brazed materials, low melting points and self-fluxing properties. On the basis of the Ni-P system, the most well-known alloys for brazing are $\mathrm{BNi}-6, \mathrm{BNi}-7$ and $\mathrm{BNi}-12$ (Fig. 3), which spread well over the surface of steels. During the development of filler metals, silicon, iron, cobalt, manganese and copper are added to the alloys of the $\mathrm{Ni}-\mathrm{P}$ system. The BNi-6 alloy is a brittle powder material based on a double eutectic in the $\mathrm{Ni}-\mathrm{P}$ system, which melts at a temperature of $880{ }^{\circ} \mathrm{C}$. It is used in products with minimum strength requirements, when it is necessary to carry out the brazing process with nickel alloy at very low temperatures. The low erosion activity of the $\mathrm{BNi}-6$ alloy makes it a good choice for thin metal profiles such as heat exchangers. The BNi-7 alloy is a ternary eutectic alloy based on the $\mathrm{Ni}-\mathrm{Cr}-\mathrm{P}$ system and contains $14 \mathrm{wt} . \% \mathrm{Cr}$. It is often used for brazing honeycomb structures, thin-walled tube assemblies, and nuclear applications where boron cannot be used. The BNi-7 alloy flows freely into the gap between the joints of the order $\sim 25 \mu \mathrm{m}$ or less and provides a hermetically sealed connection that is resistant to oxidation and electrochemical corrosion. The BNi-12 braze alloy with an increased chromium content of $25 \%$ versus $14 \%$ in the $\mathrm{BNi}-7$ is designed to improve the oxidation and corrosion resistance of the brazed joint. It is recommended for nuclear applications where boron-containing filler metals cannot be used.

\section{Filler metals based on the $\mathrm{Ni}-\mathrm{Si}-\mathrm{Be}$ and $\mathrm{Ni}-\mathrm{Cr}-\mathrm{Si}-\mathrm{Be}$ systems}

Alloys of the $\mathrm{Ni}-\mathrm{Be}$ system are known in materials science, which are promising for the creation of new filler metals. Alloying with beryllium provides high hardness, good electrical and thermal conductivity, improved strength and corrosion resistance of products made from nickel-based alloys. The action of beryllium in nickel alloys is in many ways similar to the action of boron, however, unlike boron, beryllium has a better solubility in nickel. Beryllium with nickel forms a eutectic (Table 1). To further reduce the melting point of alloys based on the $\mathrm{Ni}-\mathrm{Be}$ system, silicon alloying is used. A ternary eutectic is formed in the $\mathrm{Ni}-\mathrm{Si}-\mathrm{Be}$ system. Low-temperature alloy $\mathrm{Ni}-$ $6 \mathrm{Si}-5 \mathrm{Be}$, wt. \% melts at a temperature of $915^{\circ} \mathrm{C}$, which allows brazing of steels up to $1000{ }^{\circ} \mathrm{C}$. However, due to the high content of intermetallic compounds, the filler metal is brittle and not suitable for brazing over large gaps; it can be used for brazing over small gaps. The high content of beryllium in this alloy complicates the technological process of a braze alloy production, since work with these alloys must be carried out in compliance with special safety measures due to the toxicity of beryllium. Filler metal with a reduced beryllium content, for example $\mathrm{Ni}-5 \mathrm{Si}-3 \mathrm{Be} w \mathrm{w} . \%$, has a liquidus temperature of about $1130{ }^{\circ} \mathrm{C}$ and is plastic. It can be used for small and large gaps. The structure of the ternary eutectic in these alloys is formed by the following phases: a nickel solid solution and chemical compounds $\mathrm{NiBe}$ and $\mathrm{Ni}_{3} \mathrm{Si}$. Alloying chromium from 4 to $12 \mathrm{wt}$.\% of $\mathrm{Ni}-\mathrm{Si}-\mathrm{Be}$-based alloys practically does not change the temperatures of solidus and liquidus. Austenitic steel/ $\mathrm{Ni}-$ $\mathrm{Cr}-5 \mathrm{Si}-3 \mathrm{Be}$ brazed joints, obtained at a temperature of $1160{ }^{\circ} \mathrm{C}$ with an isothermal holding time of $40 \mathrm{~min}$, have a homogeneous structure and a tensile strength of $530 \pm 50 \mathrm{MPa}$, which corresponds to a tensile strength of the base material. The disadvantage of such alloys is their high tendency to oxidation, which leads to the formation of a dense oxide film on the filler metal and the need for its de-oxidation during the brazing process [88-90].

\section{Strength of joints made with nickel-based filler metals}

In general, the strength of the joint depends on a width of the gap, a mode of brazing, and the composition of the base material and the filler metal. When brazing steels with plastic filler metals, the mechanical characteristics 
are largely determined by the properties of the braze alloy. Further, the influence of a soldering mode and a size of the gap on resulting strength of the joints, obtained using brittle brazing alloys containing metalloids, is considered in more detail.

It was found that the morphology of the fracture of such joints depends on the structural-phase state of the brazed seam, so with insufficient holding time or too low brazing temperature, the fracture is brittle [91]. This is due to the fact that during a brazing process, an eutectic can form in a gap, concentrating mainly in a center of a seam. With an increase in the brazing temperature and holding time, the process of diffusion of metalloids $(\mathrm{B}, \mathrm{Si}, \mathrm{P})$ from a gap into the base material is activated. This makes it possible to braze wider gaps and get a seam without a eutectic structure. In the literature, the concept of the maximum brazing clearance (MBC) is used. This is the maximum

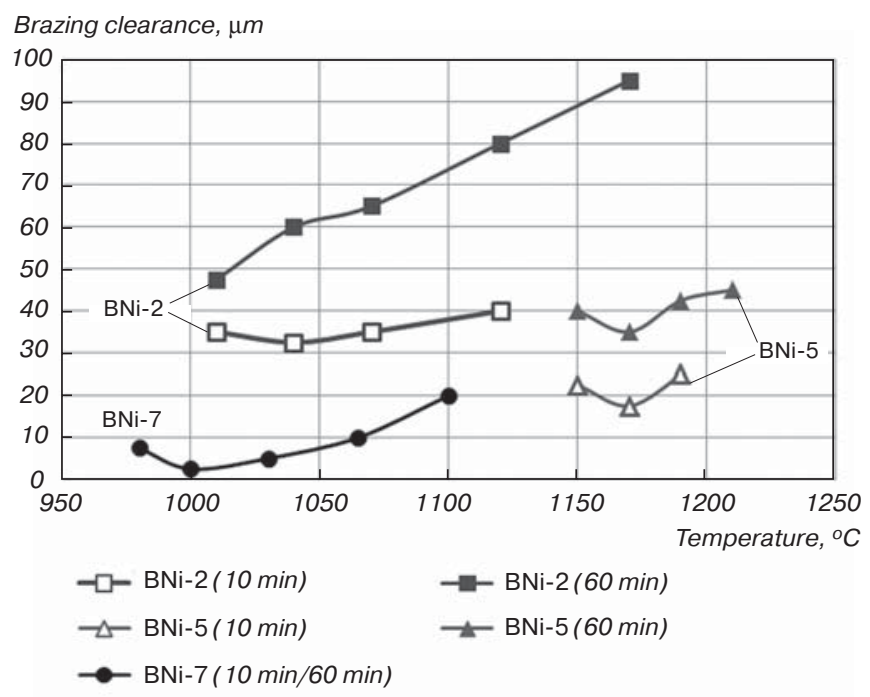

Fig. 5. Dependence of a gap size on the brazing temperature for $\mathrm{BNi}-2$, BNi-5 and BNi-7 alloys for different time modes

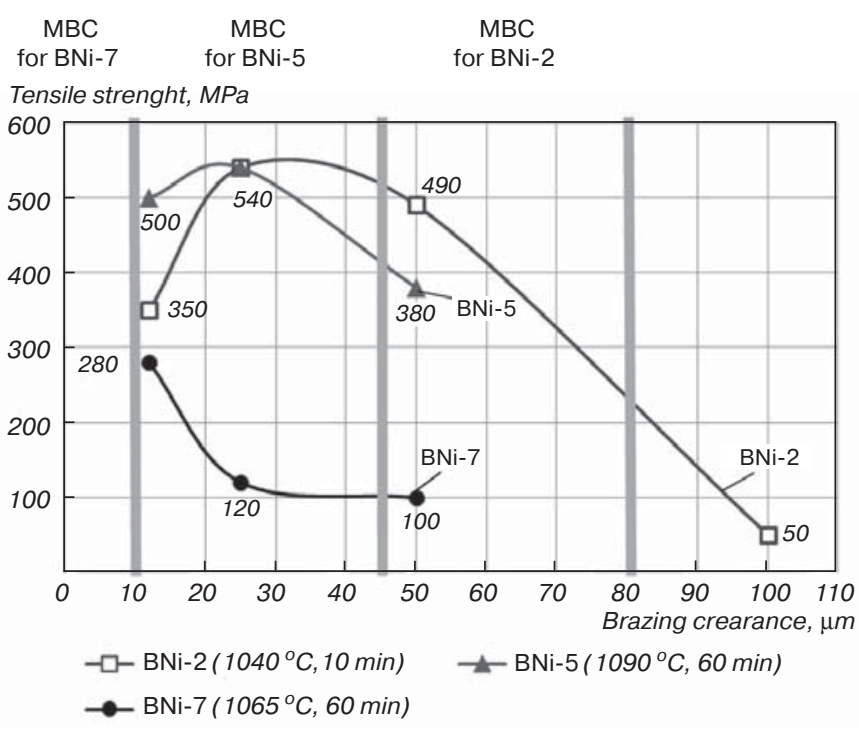

Fig. 6. Dependence of the tensile strength of brazed joint on the gap size for $\mathrm{BNi}-2, \mathrm{BNi}-5$ and $\mathrm{BNi}-7$ alloys for different braze modes gap, when there are no brittle phases that form an eutectic in the seam.

It should be borne in mind that the best strength and plastic characteristics are provided by the brazed joint, which is predominantly a solid solution. So, with a longer holding time or at a higher brazing temperature, an amount of eutectic in a seam body decreases, and an amount of a solid solution increases. Influence of a gap size on the strength of joints obtained using industrial $\mathrm{BNi}-2(\mathrm{Ni}-\mathrm{Cr}-\mathrm{Si}-\mathrm{B}), \mathrm{BNi}-5(\mathrm{Ni}-\mathrm{Cr}-\mathrm{Si})$ and BNi-7 $(\mathrm{Ni}-\mathrm{Cr}-\mathrm{P})$ brazing alloys, the most commonly used, is shown in Fig. 5.

Experiments on AISI 316 steel show that MBC strongly depends on the brazing temperature for $\mathrm{BNi}-2$ and $\mathrm{BNi}-5$ alloys and changes a little for $\mathrm{BNi}-7$ alloy. This is due to the fact that when using BNi-7 filler metal with phosphorus, iron phosphides are formed at the interface with steel. The removal of phosphorus into the base material occurs due to the growth of a dense layer of phosphides [92]. The process is associated with a diffusion of phosphorus to the steel / phosphide interface and iron to the phosphide / liquid interface. The speed of this process is low. B and $\mathrm{Si}$, unlike $\mathrm{P}$, diffuse directly into the base material, which ensures their efficient removal from a braze seam.

Studies of a brazed joint strength (Fig. 6) have shown that the use of $\mathrm{BNi}-2$ and $\mathrm{BNi}-5$ alloys, when choosing an optimal gap size and a brazing mode, allows to obtain joints with a strength equal to the strength of the base material [93]. The use of an alloy with phosphorus at any brazing parameters allows to obtain about $300 \mathrm{MPa}$, which is $(0.4-0.5) \sigma_{s}$ of the base material.

When using the BNi-2 alloy at too small gaps ( 10$15 \mu \mathrm{m})$, low mechanical characteristics are obtained. This is due to the complexity of filling such small gaps and the presence of non-brazed areas. When using the $\mathrm{BNi}-2$ alloy for gaps larger than MBC, the fracture is brittle, and the strength is about $50 \mathrm{MPa}$, which is less than $10 \%$ of the strength of the base material [94]. When using the $\mathrm{BNi}-5$ alloy for gaps larger than $\mathrm{MBC}$, it leads to values of 350-400 MPa, which indicates lower brittleness of a joint compared to the joint, obtained from the $\mathrm{BNi}-2$ alloy containing boron. Apparently, silicides formed in case of the $\mathrm{BNi}-5$ alloy do not as critically embrittle the seam as borides formed in case of the $\mathrm{BNi}-2$ alloy.

When using the BNi-7 alloy for gaps larger than MBC, it leads to obtaining strength at the level of 100-130 MPa. Therefore, its use is suitable for brazing non-critical structures that are not subjected to high loads [95].

The use of an alloy of the BNi-1 type with an increased $\mathrm{Cr}$ content, in comparison with $\mathrm{BNi}-2$, leads to an increase in strength and a decrease in the ductility of the solid solution that forms in the seam. This effect is associated with the hardening of a nickel-based solid solution.

Filler metals based on the $\mathrm{Ni}-\mathrm{Cr}-\mathrm{Si}-\mathrm{Be}$ system are similar to the $\mathrm{BNi}-5$ alloy. When brazing gaps less than the MBC, the ultimate tensile strength is at the level of a base material. With an increase in the gap above the 
$\mathrm{MBC}$, the strength drops to $50-60 \%$ of the strength of the base material, which is associated with the formation of NiBe phases in the seam.

Filler metals with a high manganese content based on solid solutions either contain too much manganese, which reduces the corrosion resistance of joints, or have a melting point that is too high. These alloys can be used to braze narrow or wide gaps. The tensile strength of the Cr18Ni10Ti/VPr7 (34 wt.\% Mn) joint, is $470 \mathrm{MPa}$. With an increase in the manganese content, for example, when using the alloy Mn70NiCr (70 wt.\% Mn, Fig. 3), the tensile strength is at the level of $390 \mathrm{MPa}$. The addition of silicon to solid solution alloys makes them eutectic, as mentioned above. The alloying of silicon leads to the formation of brittle silicides, which somewhat embrittles the joint and reduces its plastic characteristics. The tensile strength of such joints strongly depends on a gap size and a temperature-time mode of brazing, and also depends on the amount of silicon that has diffused into steel.

\section{Corrosion resistance of joints made with nickel-based filler metals}

The types of corrosion damage affecting brazed joints are similar to those of a base material. In addition to environmental influences, brazed joints are selectively affected by the geometric factor due to a small size of a seam in relation to a base material and due to an inhomogeneous microstructure. Thus, galvanic corrosion, interfacial corrosion or stress corrosion cracking is likely to occur. A joint of stainless steel, obtained with a braze alloy based on nickel or another element, is a contact of two electrochemically dissimilar metals. One of them, which has a more negative potential, functions as an anode and dissolves, while the other becomes a cathode. It is dangerous when the anode is a brazed joint or a diffusion zone. Due to their small area in comparison with the base metal, the increased density of the corrosion current leads to their rapid damage. Therefore, a braze alloy is selected in such a way that a brazed seam will be a cathode section. However, under stress conditions in a seam, it may develop its own anode areas, the appearance of which may be associated with pores, mechanical damage or chemical heterogeneity, so the corrosion process takes place in a seam itself. The most dangerous type of corrosion for steels with high chromium content is intergranular corrosion. Chromium is an active carbide-forming component. The rate of intergranular corrosion can be measured by the concentration of chromium in the steel grain. The greater the difference in chromium concentrations at the grain boundary and in the grain volume, the faster intergranular corrosion proceeds. At the same time, as mentioned earlier [82-83], some elements in a braze alloy also have a high affinity for chromium. For example, the formation of chromium borides in the diffusion zone also contributes to an increase in the difference in chromium concentration at the grain boundary and in the grain volume.
It is known that the chromium content in a braze alloy determines the corrosion resistance of a brazed joint. If the content of chromium in a braze alloy is comparable to that of a base material, the diffusion zone is not depleted in this element and provides corrosion resistance. For this, its content in the seam must be at least 13 wt.\% [13]. In addition, nickel-based brazing alloys with a high $\mathrm{Cr}$ content are characterized by a passive film with high protective properties. It was noted that in fatigue tests with the simultaneous action of a corrosive environment, the effect of the corrosive environment on the growth of a fatigue crack was not found [85]. For AISI 316L steel joints, the highest corrosion resistance in an acidic environment is demonstrated by alloys with a high chromium content, both based on the $\mathrm{Ni}-\mathrm{Cr}-\mathrm{Si}-\mathrm{B}$ and $\mathrm{Ni}-\mathrm{Cr}-\mathrm{P}$ systems [96]. In this case, the elements $\mathrm{P}, \mathrm{B}$ and $\mathrm{Si}$ have a negative effect. For alloys based on the $\mathrm{Ni}-\mathrm{Cr}-\mathrm{Si}-\mathrm{B}$ system, areas where corrosive attack occurs primarily are: areas containing $\mathrm{Ni}_{3} \mathrm{Si}$ phases, which do not contain chromium; and the diffusion zone, which contains an excessive amount of $\mathrm{Cr}_{x} \mathrm{~B}_{y}$. The destruction of the brazed seam occurs in stages [82]. The first stage is selective corrosion that occurs at contact points with an aggressive environment of a diffusion zone rich in $\mathrm{Cr}_{x} \mathrm{~B}_{y}$ and a central part of a seam rich in $\mathrm{Ni}_{3} \mathrm{Si}$. Then, through resulting cracks, the medium penetrates deep into the brazed joint, increasing the depth of damage, simultaneously causing intergranular corrosion and pitting. Thus, under loads on the joint, a crack is, as a rule, initiated and passes through the diffusion zone, where deep corrosion damage has formed.

There is also an effect of the influence of the brazing temperature on the corrosion resistance of joints. For alloys based on the $\mathrm{Ni}-\mathrm{Cr}-\mathrm{P}$ system, the tensile strength of the joint increases with increasing temperature and holding time. However, in contrast to the increase in strength, a corrosion resistance of such alloys deteriorates sharply [96]. This tendency is also traced for alloys based on the $\mathrm{Ni}-\mathrm{Cr}-\mathrm{Si}-\mathrm{B}$ system, however, it is not so pronounced.

Unlike nickel-based brazing alloys containing metalloids, brazing alloys based on the Ni-Mn system do not form intermediate phases in a seam and a diffusion zone. However, as with B and P systems, the chromium content is critical for the $\mathrm{Ni}-\mathrm{Mn}$ alloy system in the case of corrosion resistance requirements. For example, it is known that the VPr-7 alloy (Fig. 3) has a low corrosion resistance [36]. While an alloy of a similar composition, containing $18 \mathrm{wt} . \% \mathrm{Cr}$, meets requirements for corrosion resistance, although in many environments it is lower than other nickel-based brazing alloys with chromium. Thus, to increase the corrosion resistance of $\mathrm{Ni}-\mathrm{Mn}$ brazing alloys, chromium alloying is advisable. An example is the Mn70NiCr alloy (5 wt.\% Cr) (Fig. 3). However, such alloys are not suitable for use in a vacuum, since the vapor pressure of manganese is $13.3 \mathrm{~Pa}$ at a temperature of $791{ }^{\circ} \mathrm{C}$, so its sublimation is likely. Mn-containing filler metals can be oxidized when heated in a vacuum below $10^{-2}-10^{-3} \mathrm{~Pa}$. 


\section{Resume}

In general, the characteristics of nickel filler metals described above can be combined into a summary qualitative table (Table 2), containing such parameters as manufacturability, cost of alloys and physical and mechanical characteristics of brazed joints, in comparison with other filler metals discussed in the second chapter of the overview. Each parameter of the table is conventionally divided according to the scale. The brazing temperature is considered from the point of view of not deteriorating the properties of the steel. In the case of production volume and cost, all types of products were taken into account: powders, foils, etc. It is obvious that the corrosion resistance of a brazed joint in different environments will change, and it depends on a large number of factors: from the size of the seam to the temperature of the environment and the presence of certain overlapping factors (fatigue load or the presence of certain ions). Testing is required to simulate a specific operating condition in order to obtain specific information. However, due to the fact that galvanic corrosion on a larger scale is of particular importance for the brazed joint, the degree of anodic dissolution of the joint depends on the potential difference between the seam material and the steel. The parameters are considered provided that the optimal combination of gap / brazing mode / amount of filler metal is fulfilled.

\section{Summary}

Brazing has found application in many design developments and is sometimes the only solution to some of the most serious engineering problems. Existing braze alloys are adapted to many materials and operating conditions, but advances in materials science and design require continuous improvement of filler metals, which is fundamental in the case of the manufacture of components for nuclear reactors, diesel, aircraft and rocket engines, stationary gas turbines.

This overview focuses on austenitic stainless steels as it is one of the most widely used structural materials in many industries. The series of nickel-based braze alloys is the most extensive and universal for brazing of these steels. The joints obtained with these filler metals meet the highest requirements for corrosion resistance, strength and, most importantly, stability of operation at elevated

Table 2.

Comparative characteristics of filler metals considered for brazing steel

\begin{tabular}{|c|c|c|c|c|c|c|c|c|c|c|c|c|}
\hline \multirow[b]{3}{*}{$\begin{array}{c}\text { Filler metal / } \\
\text { (brazed joint) property }\end{array}$} & \multicolumn{11}{|c|}{ Filler metal composition } & \multirow[b]{3}{*}{ Note } \\
\hline & \multicolumn{2}{|c|}{$\mathrm{Cu}$} & \multirow[b]{2}{*}{ 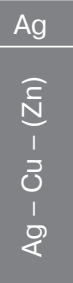 } & \multirow[b]{2}{*}{ 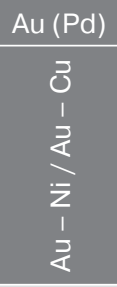 } & \multicolumn{2}{|c|}{$\mathrm{Fe}$} & \multicolumn{5}{|c|}{$\mathrm{Ni}$} & \\
\hline & $\vec{U}$ & $\sum_{\substack{1 \\
J}}^{5}$ & & & $\begin{array}{l}m \\
1 \\
\dot{\omega} \\
1 \\
0 \\
\longleftarrow\end{array}$ & $\begin{array}{l}0 \\
1 \\
\frac{1}{0} \\
1 \\
\frac{Z}{Z} \\
1 \\
0 \\
\mathbb{L}\end{array}$ & $\begin{array}{l}m \\
\frac{1}{\omega} \\
\frac{1}{z}\end{array}$ & $\begin{array}{l}\frac{0}{1} \\
\frac{1}{z}\end{array}$ & $\begin{array}{l}\bar{\omega} \\
1 \\
\bar{U} \\
\frac{1}{Z} \\
\bar{z}\end{array}$ & $\begin{array}{l}j \\
1 \\
\frac{1}{\Sigma} \\
\frac{1}{z}\end{array}$ & $\begin{array}{l}\infty \\
\infty \\
1 \\
\frac{1}{z}\end{array}$ & \\
\hline Brazing temperature & ++ & + & + & ++ & +++ & ++ & ++ & + & +++ & ++ & +++ & $\begin{array}{l}\text { + till to } 950^{\circ} \mathrm{C} \\
\text { ++ } 950-1100^{\circ} \mathrm{C} \\
\text { +++ up to } 1100^{\circ} \mathrm{C}\end{array}$ \\
\hline Wettability & - & + & + & + & + & + & + & + & - & + & - & $\begin{array}{l}\text { - small } \\
\text { + high }\end{array}$ \\
\hline Manufacturability & MM & M & M & M & $M$ & $\mathrm{M}$ & $\mathrm{MM}$ & $\mathrm{M}$ & MM & M & - & $\begin{array}{l}\mathrm{M} \text { - easy for using } \\
\mathrm{MM} \text { - easy for using } \\
\text { and production }\end{array}$ \\
\hline Production volume & +++ & +++ & +++ & + & + & + & ++ & ++ & ++ & + & - & $\begin{array}{l}\text { + small } \\
++ \text { middle } \\
+++ \text { large } \\
\end{array}$ \\
\hline Cost & + & + & + & +++ & ++ & ++ & ++ & ++ & ++ & ++ & ++ & $\begin{array}{l}\text { + low } \\
++ \text { middle } \\
+++ \text { high }\end{array}$ \\
\hline $\begin{array}{l}\text { Heat resistance } \\
\text { (Working } T \text { ) }\end{array}$ & + & + & + & ++ & ++ & + & ++ & + & ++ & ++ & ++ & $\begin{array}{l}\text { + till to } 700^{\circ} \mathrm{C} \\
\text { ++ up to } 700^{\circ} \mathrm{C}\end{array}$ \\
\hline Strength properties & + & + & + & ++ & + & - & ++ & - & ++ & ++ & ++ & $\begin{array}{l}\text { - below } 0.5 \text { steel } \\
\text { strength } \\
+0.5-0.8 \text { steel } \\
\text { strength } \\
++ \text { above } 0.8 \\
\text { steel strength }\end{array}$ \\
\hline $\begin{array}{l}\text { Resistance to } \\
\text { electrochemical } \\
\text { corrosion }\end{array}$ & - & - & + & ++ & + & ++ & + & ++ & ++ & + & + & $\begin{array}{l}\text { - weak resistance } \\
\text { + satisfactory resistance } \\
\text { ++ high resistance }\end{array}$ \\
\hline
\end{tabular}


temperatures $\left(600 \ldots 800{ }^{\circ} \mathrm{C}\right)$, since they have a de-brazing temperature comparable to the melting point of steel. The most "popular" filler metals are alloys based on solid solutions with precious metals ( $\mathrm{Au}, \mathrm{Pd})$ and eutectic alloys based on the $\mathrm{Ni}-\mathrm{Cr}-\mathrm{Si}-\mathrm{B}$ and $\mathrm{Ni}-\mathrm{Cr}-\mathrm{Si}$ systems.

Recently, the development and modification of nickelbased brazing alloys occurs in the direction of lowering the content of boron and phosphorus to amounts that minimize the formation of brittle phases in the diffusion zone during the brazing process. And also in the direction of optimizing the silicon content in order to increase the strength and ductility of brazed joints, without losing corrosion resistance and low melting point, by introducing additional alloying elements or replacing them with more suitable properties.

Also, the modern trend is the demand for partial or complete replacement of nickel with iron. This is due to the high cost of nickel-based filler metals and stricter environmental requirements.

Thus, due to the huge range of development directions, the trajectory for choosing the composition of the braze alloy to obtain optimal technological parameters, mechanical characteristics and corrosion resistance of the joints must be determined for a specific design task.

\section{Acknowledgments}

\section{The reported study was funded by RFBR, project number 20-12-50106.}

\section{References}

1. Way M., Willingham J., Goodall R. Brazing Filler Metals. International Materials Reviews. 2020. Vol. 65, Iss. 5. pp. $257-$ 285. DOI: 10.1080/09506608.2019.1613311

2. Simöes S. Diffusion Bonding and Brazing of Advanced Materials. Metals. 2018. Vol. 8, Iss. 11. pp. 959. DOI: 10.3390/ met8110959

3. Dieter S., Fortuna D. Selecting Materials for Brazing a Honeycomb in Turbine Engines. Welding Journal. Vol. 93, Iss. 2. 2014. pp. 44-48.

4. Ulan kyzy S., Völkl R., Munz O., Fischer T., Glatzel U. The Effect of Brazing on Microstructure of Honeycomb Liner Material Hastelloy X. Journal of Materials Engineering and Performance. 2019. Vol. 28, Iss. 4. pp. 1909-1913. DOI: 10.1007/ s11665-019-03910-w

5. Eustathopoulos N., Hodaj F., Kozlova O. The Wetting Process in Brazing. In book: Advances in Brazing: Science, Technology and Applications. 2013. pp. 3-30. DOI: 10.1533/ 9780857096500.1 .3

6. Jiang W., Gong J. M., Tu S. T. Effect of Holding Time on Vacuum Brazing for a Stainless Steel Plate-Fin Structure. Materials and Design. 2010. Vol. 31. Iss. 4. pp. 2157-2162. DOI: 10.1016/j.matdes.2009.11.001

7. Mizokami Y., Igari T., Kawashima F., Sakakibara N., Tanihira M., Yuhara T., Hiroe T. Development of Structural Design Procedure of Plate-fin Heat Exchanger for HTGR. Nuclear Engineering and Design. 2013. Vol. 255. pp. 248-262.

8. June Kee Min, Ji Hwan Jeong, Man Yeong Ha, Kui Soon Kim. High Temperature Heat Exchanger Studies for Appli- cations to Gas Turbines. Heat Mass Transfer. 2009. Vol. 46, Iss. 2. pp. 175-186. DOI: 10.1007/s00231-009-0560-3

9. Alfred I., Nicolaus M., Hermsdorf J., Kaierle S., Mö hwald K., Maier H.-J., Wesling V. Advanced High Pressure Turbine Blade Repair Technologies. Procedia CIRP. 2018. Vol. 74. pp. 214-217. DOI: 10.1016/j.procir.2018.08.097

10. Nicolaus M., Rottwinkel B., Alfred I., Möhwald K., Nölke C., Kaierle S., Maier H. J., Wesling V. Future Regeneration Processes for High-Pressure Turbine Blades. CEAS Aeronautical Journal. 2017. Vol. 9, Iss. 1. pp. 85-92. DOI: 10.1007/s13272017-0277-9

11. MacDonald W. D., Eagar T. W. Transient Liquid Phase Bonding. Annual Review of Materials Science. 1992. Vol. 22, Iss. 1. pp. 23-46.

12. Noto H., Kasasa R., Kimura A., Ukai S. Grain Refinement of Transient Liquid Phase Bonding Zone Using ODS Insert Foil. Journal of Nuclear Materials. 2013. Vol. 442, Iss. 1-3. pp. S567-S571. DOI: 10.1016/j.jnucmat.2013.04.054

13. Jalilian F., Jahazi M., Drew R. A. L. Microstructural evolution during transient liquid phase bonding of Inconel 617 using $\mathrm{Ni}-\mathrm{Si}-\mathrm{B}$ filler metal. Materials Science and Engineering: A. 2006. Vol. 423, Iss. 1-2. pp. 269-281.

14. Shakerin S., Maleki V., Ziaei S. A., Omidvar H., Rahimipour M. R., Mirsalehi S. E. Microstructural and Mechanical Assessment of Transient Liquid Phase Bonded Commercially Pure Titanium. Canadian Metallurgical Quarterly. 2017. Vol. 56, Iss. 3. pp. 360-367. DOI: 10.1080/00084433.2017.1349024

15. Abdolvand R., Atapour M., Shamanian M., Allafchian A. The Effect of Bonding Time on The Microstructure and Mechanical Properties of Transient Liquid Phase Bonding between SAF 2507 and AISI 304. Journal of Manufacturing Processes. 2017. Vol. 25. pp. 172-180. DOI: 10.1016/j.jmapro. 2016.11.013

16. Cook G. O., Sorensen C. D. Overview of Transient Liquid Phase and Partial Transient Liquid Phase Bonding. Journal of Materials Science. 2011. Vol. 46, Iss. 16. pp. 5305-5323.

17. Arafin M., Medraj M, Turner D. et al. Effect of Alloying Elements on the Isothermal Solidification During TLP Bonding of SS 410 and SS 321 Using a BNi-2 Interlayer. Materials Chemistry and Physics. 2007. Vol. 106, Iss. 1. pp. 109-119.

18. Chen J. Vacuum Braze of Stainless Steel Joints With Wide Clearance. Journal of the University of Petroleum, China (Natural Science Edition). 1999. Vol. 23. Iss. 6. pp. 53-56.

19. Corbin S. F., Murray D. C., Bouthillier A. Analysis of Diffusional Solidification in a Wide-Gap Brazing Powder Mixture Using Differential Scanning Calorimetry. Metallurgical and Materials Transactions A. 2016. Vol. 47, Iss. 12. pp. 63396352. DOI: $10.1007 / \mathrm{s} 11661-016-3799-6$

20. Yan G., Bhowmik A., Nagarajan B., Song X., Tan S. C., Tan M. J. Bonding Temperature Effects on the Wide Gap Transient Liquid Phase Bonding of Inconel 718 Using Bni-2 Paste Filler Metal. Applied Surface Science. 2019. Vol. 484. pp. 1223-1233. DOI: 10.1016/j.apsusc.2019.04.070

21. Huang X., Miglietti W. Wide Gap Braze Repair of Gas Turbine Blades and Vanes - a Review. Journal of Engineering for Gas Turbines and Power. 2012. Vol. 134. Iss 1. DOI: 10.1115/ 1.4003962 
22. Sakai M., Sasaki T., Miyazawa Y. Mechanism of Void Formation During Brazing of Ni Paste Brazing Filler Metal. Materials Science Forum. 2021. Vol. 1016. pp. 1218-1222.

23. Sharma A., Lee S.-J., Oh J.-H., Jung J. P. AISI 304 Steel Brazing Using a Flexible Brazing Foil Fabricated by Tape Casting Method. Journal of Korean Institute of Metals and Materials. 2017. Vol. 55, Iss. 12. pp. 836-844.

24. Rabinkin A. Brazing with Amorphous Foil Performs. Advanced Materials and Processes. 2001. Vol. 159, Iss. 6. pp. 65-67.

25. Cadden C. H. Brazing. Encyclopedia of Materials: Science and Technology. 2006. pp. 1-7.

26. Fortuna D. Manufacture of Braze and Solder Alloy Powders by Atomization. Welding Journal. 2004. Vol. 83, Iss. 10. pp. 40-44.

27. ASM International. Handbook Committee. ASM handbook. 1996. 1057 p.

28. Paidar M., Ashraff Ali K., Ojo O. O., Mohanavel V., Vairamuthu J., Ravichandran M. Diffusion Brazing of Inconel 617 and 321 Stainless Steel by Using AMS 4772 Ag Interlayer. Journal of Manufacturing Processes. 2021. Vol. 61. pp. 383-395.

29. Hebda M., Kaczor P., Miernik K. Vacuum Brazing of Stainless Steel Depending on the Surface Preparation Method and Temperature of the Process. Archives of Metallurgy and Materials. 2019. Vol. 64, Iss. 1. pp. 5-11.

30. Shiue R.-K., Wu S.-K., Chen C.-P., Yang S.-H. Infrared brazing of Ti $50 \mathrm{Ni} 50$ shape memory alloy and 316L stainless steel with $\mathrm{Au}-22 \mathrm{Ni}-8 \mathrm{Pd}$ filler. Gold Bulletin. 2015. Vol. 48, Iss. 1-2. pp. 57-62. DOI: 10.1007/s13404-015-0160-6

31. Schmiedt-kalenborn A., Lingnau L., Manka M., Tillmann W., Walther F. Fatigue and Corrosion Fatigue Behaviour of Brazed Stainless Steel Joints AISI 304L / BAu-4 in Synthetic Exhaust Gas Condensate. Materials. 2019. Vol. 12, Iss. 7. p. 1040. DOI: $10.3390 / \mathrm{ma} 12071040$

32. Tillmann W., Wojarski L., Manka M., Trelenberg A. Investigation of the Brazing Characteristics of a New Iron-Based Brazing Filler Metal. Welding in the World. 2016. Vol. 60, Iss. 5. pp. 869-875. DOI: 10.1007/s40194-016-0346-4

33. Epelbaum C., Fontana M., Audebert F., Arcondo B. Joining Steel Tubes Employing $\mathrm{Fe}-\mathrm{Si}-\mathrm{B}$ Metallic. Journal of Materials Science. 2005. Vol. 40, Iss. 18. pp. 4867-4871.

34. Li H., Zhang X., Mårs O., Zhao O., Lu Q., Chen Z. The Effect of Iron-Based Filler Metal Element on the Properties of Brazed Stainless Steel Joints for EGR Cooler Applications. Welding in the World. 2019. Vol. 63, Iss. 2. pp. 263-275.

35. Weinstein M., Lee L., Johnson L., Battenbough A., Osmanda A. M. Properties of Selected Nickel and Iron Based Brazing Filler Metals. 2015. URL: https://www.wallcolmonoy. com/ wp-content/uploads/2015/05/Wall-Colmonoy-Properties- ofSelected-Ni-and-Fe-Based-Brazing-Filler-Metals.pdf (accessed: 19.05.2021)

36. Chorunov V. F. Fundamentals of Soldering Thin-Walled Structures from High-Alloy Steels. Kiev: Isdatelstvo Naukova Dumka, 2008. 238 p.

37. Khimushin F. F. Stainless Steels. Moscow: Metallurgiya, 1967. $800 \mathrm{p}$.

38. Physical Materials Science. Vol. 6, Pt.1: Structural Materials of Nuclear Engineering. Ed. by Kalin B. A. Moscow: MEPhI, 2008. 672 p.
39. Villars P., Okamoto H. Binary Phase Diagram: Datasheet from "PAULING FILE Multinaries Edition - 2012" in SpringerMaterials. URL: https://materials.springer.com/isp/ phase-diagram/docs/c_0907931. (accessed: 19.05.2021)

40. Su Yu, Yu Zhishui, Yan Zhi, Li Jun, Huang Guo. Effects of Composite Nickel-base Boracic Brazing Filler on the Boride Near the Brazing Seam of 316L Stainless Steel. Advanced Materials Research. 2012. Vol. 535-537. pp. 730-733.

41. Wei Z., Jiang W., Song M., Xiao C., Tu S.-T. Effects of Element Diffusion on Microstructure Evolution and Residual Stresses in a Brazed Joint: Experimental and Numerical Modeling. Materialia. 2018. Vol. 4. pp. 540-548.

42. Penyaz M. A., Ivannikov A. A., Kalin B. A., Dzhumaev P. S. Thermal Fatigue Damage of Steel Joints Brazed with Various Nickel Filler Metals. Non-ferrous Metals. 2019. No. 1. pp. 33-39. DOI: 10.17580/nfm.2019.01.06

43. Zhou K., Zhang T. Induction Brazing of 304 Stainless Steel with a Metalloid-Free $\mathrm{Ni}-\mathrm{Zr}-\mathrm{Ti}-\mathrm{Al}-\mathrm{Sn}$ Amorphous Foil. Materials Transactions. 2017. Vol. 58, Iss. 4. pp. 663-667. DOI: 10.2320/matertrans.M2016319.

44. Park T.G., Yi S., Kim D. H. Development of New Nibased Amorphous Alloys Containing No Metalloid That Have Large Undercooled Liquid Regions. Scripta Materialia. 2000. Vol. 43, Iss. 2. pp. 109-114.

45. Ivannikov A. A., Sevryukov O. N., Penyaz M. A., Popov N. S. Development of Nickel-Based Filler Metal for Producing High-Strength Joints in Critical Products from Heat-Resistant Materials. Non-ferrous Metals. 2018. No. 2. pp. 43-49. DOI: 10.17580/nfm.2018.02.08

46. Huang X. Microstructure and Oxidation Behaviour of NGB and WGB Joints with Boron/Silicon Free Nickel Base Braze Alloys. Proceedings of the ASME Turbo Expo. 2020. Vol. 8. DOI: 10.1115/GT2020-14017.

47. Lukin V. I., Rylnikov V. S., Afanasyev-Khodykin A. N. A Nickel-Based Brazing Alloy for Brazing Creep-Resisting Alloys and Steels. Welding International. 2015. Vol. 29, Iss. 7. pp. 567-572.

48. Fedotov V. T., Suchkov A. N., Kalin B. A., Sevryukov O. N., Ivannikov A. A. Rapidly Quenched Filler Metal STEMET for Brazing of Materials of Modern Technology. Tsvetnye Metally. 2014. No. 12. pp. 32-37.

49. Moradi M. J., Emadoddin E., Omidvar H. The Joint Properties of A564-630 Stainless Steel Made by Transient Liquid Phase Bonding: Microstructural and Mechanical Strength Evaluation. Journal of Materials Engineering and Performance. 2020. Vol. 29, Iss. 7. pp. 4745-4753. DOI: 10.1007/s11665-02004962-z.

50. Lamjiri R. J., Ekrami A. Transient Liquid Diffusion Bonding of AISI304 Stainless Steel with a Nickel Base Interlayer. Defect and Diffusion Forum. 2017. Vol. 380. pp. 48-54. DOI: 10.4028/www.scientific.net/DDF.380.48.

51. Lin C., Shiue R.-K., Wu S.-K., Huang H.-L. Infrared Brazing of CoCrFeMnNi Equiatomic High Entropy Alloy Using Nickel-Based Braze Alloys. Entropy. 2019. Vol. 21, Iss. 3. 283. DOI: $10.3390 / \mathrm{e} 21030283$.

52. Lin C., Shiue R.-K., Wu S.-K., Lin Yu.-S. Dissimilar Infrared Brazing of $\mathrm{CoCrFe}(\mathrm{Mn}) \mathrm{Ni}$ Equiatomic High Entropy 
Alloys and 316 Stainless Steel. Crystals. 2019. Vol. 9, Iss.10. DOI: $10.3390 /$ cryst9100518.

53. Ghaderi S., Karimzadeh F., Ashra A. Evaluation of Microstructure and Mechanical Properties of Transient Liquid Phase Bonding of Inconel 718 and Nano/Ultrafine-Grained 304L Stainless Steel. Journal of Manufacturing Processes. 2020. Vol. 49. pp. 162-174.

54. Ghaderi S., Karimzadeh F., Ashrafi A., Hosseini S. H. Effect of Pressure, Temperature and Homogenization on the Dissolution Behavior and Mechanical Properties of IN718 / AISI 304 During Transient Liquid Phase Bonding. Journal of Manufacturing Processes. 2020. Vol. 60. pp. 213-226.

55. Binesh B. Diffusion Brazing of IN718 / AISI 316L Dissimilar Joint: Microstructure Evolution and Mechanical Properties. Journal of Manufacturing Processes. 2020. Vol. 57. pp. 196-208.

56. Baharzadeh E., Shamanian M., Rafiei M., Mostaan H. Properties of IN X-750 / BNi-2 / SAF 2205 Joints Formed by Transient Liquid Phase Bonding. Journal of Materials Processing Technology. 2019. Vol. 274. 116297. DOI: 10.1016/j.jmatprotec.2019.116297.

57. Baharzadeh E., Shamanian M., Rafiei M., Mostaan H. Microstructural and Mechanical Evaluations of Transient Liquid Phase Bonded In X-750 / BNi-3 / SAF 2205. Journal of Materials Engineering and Performance. 2019. DOI: 10.1007/ s11665-020-04620-4.

58. Jafari M., Rafiel M., Mostaan H. Effect of Solidification Mode on Microstructure and Mechanical Properties of AISI420 Steel to SAF2507 Steel Dissimilar Joint Produced by Transient Liquid Phase. Metals and Materials International. 2020. Vol. 26, Iss. 10. pp. 533-1544.

59. Tokunaga T., Nishio K., Ohtani H., Hesebe M. Phase Equilibria in the $\mathrm{Ni}-\mathrm{Si}-\mathrm{B}$ System. Materials Transactions. 2003. Vol. 44, Iss. 9. pp. 1651-1654.

60. Lugscheider E., Knotek O., Kloehn K. Development of Nickel-Chromium-Silicon Base Filler Metals. Journal of Welding Research Supplement. 1978. Vol. 57. Iss. 10. pp. 319323.

61. Tokunaga T., Nishio K., Hasebe M. Thermodynamic Study of Phase Equilibria in the Ni-Si-B System. Journal of Phase Equilibria. 2001. Vol. 22, Iss. 3. pp. 291-299.

62. Siredey-Schwaller N., Hamel-Akr J., Peltier L., Hazotte A., Bocher P. Solidification sequence of $\mathrm{Ni}-\mathrm{Si}-\mathrm{Cr}$ $\sim 3 \mathrm{wt} \% \mathrm{~B}$ brazing alloys. Welding in the World. 2017. Vol. 61, Iss. 6 . pp. 1253-1265. DOI: 10.1007/s40194-017-0503-4

63. Lebrun N., Perrot P., Serbruyns A., Tedenac J.-C., Effenberg G. (ed.). B - Ni - Si Ternary Phase Diagram Evaluation. Phase diagrams, crystallographic and thermodynamic data: Datasheet from MSI Eureka in SpringerMaterials. MSI Materials Science International Services GmbH, Stuttgart. 2014. URL: https://materials.springer.com $/ \mathrm{msi} / \mathrm{docs} / \mathrm{sm}_{-}$ msi_r_10_014653_01 (accessed: 19.05.2021)

64. Chen Y., Cui H., Lu B., Lu F. The Microstructural Evolution of Vacuum Brazed 1Cr18Ni9Ti Using Various Filler Metals. Materials. 2017. Vol. 10, Iss. 4. p. 385.

65. Chen Z. J., Yang C. J., Gu X. L., Wu C. D., Feng L. L. Effect of Brazing Temperature and Clearance on Microstructure and Mechanical Properties of 316L Stainless Steel Brazed Joints. Advanced Materials Research. 2012. Vol. 418-420. pp. 1242-1245.

66. Chen H., Gong J.-M., Tu S.-T. Numerical Modelling and Experimental Investigation of Diffusion Brazing SS304/ BNi2/SS304 Joint. Science and Technology of Welding and Joining. 2009. Vol. 14. Iss. 1. pp. 32-41.

67. Zorc B., Kosec L. Comparison of Brazed Joints Made with BNi-1 and BNi-7 Nickel-Base Brazing Alloys. Revista de Metalurgia. 2000. Vol. 36, Iss 2. pp. 100-107.

68. Kawakatsu I., Osawa T., Saito H. Brazed Joint Strength of Stainless Steel With Nickel Base Filler Metals. Nippon Kinzoku Gakkai-si. 1979. Vol. 43, Iss 11. pp. 1001-1007.

69. Moreau E. D., Corbin S. F. The Role of Base Metal Chromium in Determining the TLPB Behavior of Ni-Based Alloys Using a Boron-Containing Braze. Metallurgical and Materials Transactions A. 2020. Vol. 51, Iss 8. pp. 3906-3919.

70. Han W. P., Wan M., Zhao R., Kang H., Cheng C., Wang C. J. Effect of post-bond heat treatment on microstructural evolution and mechanical properties of brazed ultrathinwalled structure. Materials Science and Engineering: A. 2019. Vol. 742. pp. 680-691.

71. Logvenchev I. S., Ivannikov A. A., Volkov A. A., Arofikin N. V., Sevryukov O. N., Fedotov V. T., Suchkov A. N., Fedotov I. V., Skrytnyi V. I. The Brazing of Nickel Alloys for Nuclear Reactor with the Using of the Rapidly-Quenched Filler Metals. Inorganic Materials: Applied Research. 2014. Vol. 5, Iss. 3. pp. 263-267.

72. Bakhtiari R., Misaghi M., Eisaabadi B. Optimizing the Process Parameters for TLP Bonding of AISI 321 Stainless Steel. Metallography, Microstructure, and Analysis. 2020. Vol. 9, Iss. 2. pp. 239-251.

73. Maksimova S. V. Amorphous Filler Metals for Brazing of Stainless Steel and Titanium, and Structure Of Brazed Joints. Adhesion of Melts and Brazing of Materials. 2007. Vol. 40. pp. 70-81.

74. Alhazaa A., Haneklaus N. Diffusion Bonding and Transient Liquid Phase (TLP) Bonding of Type 304 and 316 Austenitic Stainless Steel - A Review of Similar and Dissimilar Material Joints. Metals. 2020. Vol. 10, Iss. 5. p. 613.

75. Penyaz M. A., Popov N. S., Ivannikov A. A., Sevryukov O. N. Alloying-Dependent Microstructure Influence on Corrosion Resistance of AISI 321 Cell Joints Brazed by NiBased Filler Metals. Non-ferrous Metals. 2020. No. 1. pp. 41-48. DOI: $10.17580 / \mathrm{nfm} .2020 .01 .07$

76. Xiao C., Jiang W., Yu Y., Song M., Tu S.-T., Gong J. Influence of Borides Dissolution During the Homogenization Treatment on the Mechanical Properties and Fracture Behavior of Austenitic Stainless Steel Brazed Joints. Materials Science and Engineering: A. 2020. Vol. 782. 139200. DOI: 10.1016/j.msea. 2020.139200 .

77. Moreau E. D., Corbin S. F. Assessing the Influence of $\mathrm{Cr}$ and $\mathrm{Fe}$ in the Filler Metal on Dissolution and Isothermal Solidification Kinetics During TLPB of Ni-Based Superalloys. Metallurgical and Materials Transactions A. 2020. Vol. 51, Iss. 12. pp. 6307-6317.

78. Doroudi A., Dastgheib A., Omidvar H. The Bonding Temperature Effect of the Diffusion Brazing Inconel 625 
Superalloy on the Microstructure Changes, Corrosion Resistance, and Mechanical Properties. Journal of Manufacturing Processes. 2020. Vol. 53. pp. 213-222.

79. Karlsson L., Nordén H., Odelius H. Overview no. 63. Non-equilibrium Grain Boundary Segregation of Boron in Austenitic Stainless Steel - I. Large Scale Segregation Behaviour. Acta Metallurgica. 1988. Vol. 36. Iss. 1. pp. 1-12.

80. Moreau E. D., Corbin S. F. Application of Diffusion Path Analysis to Understand the Mechanisms of Transient Liquid-Phase Bonding in the $\mathrm{Ni}-\mathrm{Si}-\mathrm{B}$ System. Metallurgical and Materials Transactions A. 2019. Vol. 50, Iss. 12. pp. 56785688 .

81. Jang J. S. C., Shih H. P. Evolution Of Microstructure Of AISI 304 Stainless Steel Joint Brazed By Mechanically Alloyed Nickel Base Filler With Different Silicon Content. Journal of Materials Science Letters. 2003. Vol. 22, Iss. 1. pp. 79-82.

82. Tillmann W., Walther F., Manka M., Schmiedt A., Wojarski L., Eilers A., Reker D. W. Investigations of the Corrosion Damage Process of the Brazed Joint AISI 304L/BNi-2. Results in Physics. 2019. Vol. 12. pp. 1245-1252.

83. Schmiedt A., Manka M., Tillmann W., Walther F. Characterisation of the Corrosion Fatigue Behaviour of Brazed AISI 304L/BNi-2 Joints in Synthetic Exhaust Gas Condensate. Welding in the World. 2018. Vol. 62, Iss 3. pp. 617-627.

84. Schmiedt A. et al. Influence of Condensate Corrosion on Tensile and Fatigue Properties of Brazed Stainless Steel Joints AISI 304L/BNi-2 for Automotive Exhaust Systems. Materialwissenschaft und Werkstofftechnik. 2018. Vol. 49, Iss. 3. pp. 249-263.

85. Otto J. L., Penyaz M., Schmiedt-Kalenborn A., Knyazeva M., Ivannikov A., Kalin B., Walther F. Effect of Phase Formation Due to Holding Time of Vacuum Brazed Aisi 304l/ Nicrsib Joints on Corrosion Fatigue Properties. Journal of Materials Research and Technology. 2020. Vol. 9, Iss 5. pp. 1055010558.

86. Ivannikov A. A., Penyaz M. A., Dzhumaev P. S., Bachurina D. M., Sevriukov O. N. Diffusion Brazing of Stainless Steels Influence of Ni-B Filler Alloy Composition. Welding in the World. 2021. Vol. 65. Iss. 2. pp. 317-328.

87. Hartmann T., Nützel D. NiFe Brazing Foils with Melting Temperatures $<1000^{\circ} \mathrm{C}$. Proceedings of the $8^{\text {th }}$ International Con- ference on Brazing, High Temperature Brazing and Diffusion Bonding, LÖT 2007, Aachen (DVS Berichte 243). 2007. pp. 23-27.

88. Ivannikov A., Fedotov V., Suchkov A., Penyaz M., Fedotov I., Tarasov B. The Use of $\mathrm{Ni}-\mathrm{Cr}-\mathrm{Si}-\mathrm{Be}$ Filler Metals for Brazing of Stainless Steels. IOP Conference Series: Materials Science and Engineering. 2016. Vol. 130. 012045. DOI: $10.1088 / 1757-899 x / 130 / 1 / 012045$

89. Ivannikov A., Kalin B., Suchkov A., Penyaz M., Yurlova M. Development of Rapidly Quenched Nickel-Based NonBoron Filler Metals for Brazing Corrosion Resistant Steels. IOP Conference Series: Materials Science and Engineering. 2016. Vol. 130. 012044. DOI: 10.1088/1757-899x/130/1/012044

90. Ivannikov A. A., Kalin B. A., Sevryukov O. N., Penyaz M. A., Fedotov I. V., Misnikov V. E., Tarasova M. S. Study of the Ni $\mathrm{Si}-\mathrm{Be}$ System as a Base to Create Boron-Free Brazing Filler Metals. Science and Technology of Welding and Joining. 2017. Vol. 23, Iss. 3. pp. 187-197.

91. Otto J. L., Penyaz M., Möhring K., Gerdes L., Schaum T., Ivannikov A., Schmiedt-Kalenborn A., Kalin B., Walther F. Microstructure, Residual Stresses, and Strain-Rate-Dependent Deformation and Fracture Behavior of AISI 304L Joints Brazed with NiCrSiB Filler Metals. Metals. 2021. Vol. 11, Iss. 4. p. 593.

92. Qin Y., Jiang W. Microstructure and Mechanical Properties of 316L Stainless Steel Joints Brazed by BNi-7 Alloyed with Different Cu Content. Welding in the World. 2019. Vol. 63, Iss. 5. pp. 1469-1475.

93. Rabinkin A. Brazing with ( NiCoCr) - B - Si Amorphous Brazing Filler Metals: Alloys, Processing, Joint Structure, Properties, Applications. Science and Technology of Welding and Joining. 2004. Vol. 9, Iss. 3. pp. 181-199.

94. Ivannikov A. A., Tukhbatov V. A., Suchkov A. N., Ustyuzhaninov A. L., Bogachev I. A. Rapidly Quenched Nickel Based Filler Metal for High Temperature Various Constructive Elements Brazing. Tsvetnye Metally. 2014. No. 12. pp. 27-31.

95. Lugscheider E., Partz K.-D. High Temperature Brazing of Stainless Steel with Nickel-Base Filler Metals BNi-2, BNi-5 and BNi-7. Welding Journal, WRS. 1983. pp. 160-s-164-s.

96. Hartmann T., Nützel D. Nickel-Chromium-Based Amorphous Brazing Foils for Continuous Furnace Brazing of Stainless Steel. Proceedings of the $9^{\text {th }}$ Conference on Brazing, High Temperature Brazing and Diffusion Bonding, LÖT 2010, Aachen (DVS Berichte 263). 2010. pp. 42-47. 